\title{
Administering Identity: The Determination of "Race" in Race- Conscious Law
}

\author{
Christopher A. Ford $\dagger$
}

Modern American anti-discrimination law seeks to remedy the effects of racial and ethnic prejudice by ensuring equality in areas such as political access and employment opportunity. In this effort, the concept of race is central both to identifying and to rectifying the effects of prejudice. Various economic and social benefits, for example, are awarded based upon injuries and solutions defined with reference to racial categories. Race and ethnicity, however, are today recognized as being largely social constructs with little empirical or scientific basis. This dichotomy between the importance of race classification to anti-discrimination law and its fundamental indeterminacy creates what the author calls a core dilemma of modern race-conscious law: the difficulties of how we "administer race." He explores two related questions bearing on this dilemma. How should the law-indeed, can the law-intelligibly define the nature and boundaries of the groups to whom remedial preferences are addressed? Furthermore, can the law "accurately" sort individuals into these groups once they have been defined? The author explores the approaches several different group conscious programs and legal regimes have taken in attempting to deal with these questions, from methods employed in sex and Native American classification to the systems of classification used in the Jim Crow South, in modern India and in South Africa during the apartheid era.

I

ADMINISTERING IDENTTTY

Today, our laws and governmental regulations establislı an enormously elaborate system of race-conscious policy, seeking to remedy the ill effects of past discrimination, to break down barriers to minority advancement, and to allocate various sorts of social and economic benefits to those made

Copyright (C) 1994 California Law Review, Inc.

$\dagger$ Christopher Ford received his A.B. from Harvard in 1989 and his D.Phil. from Oxford University (Christ Church) in 1992. He worked as a Junior Research Fellow at Wolfson College, Oxford, in 1991-92. The author is grateful to Professors Bruce Ackerman of the Yale Law School and Robert Post of the Boalt Hall School of Law at the University of California, Berkeley, for their guidance and encouragement. Most of all, however, he wishes to thank his wife Jennifer L. Davis-Ford for her boundless love, kindness, and patience. 
needy by societal prejudice and contempt. Race is no longer strictly a factor that we aspire to render as irrelevant as the color of one's eyes. It is a cornerstone of modern jurisprudence. We cannot, therefore, avoid answering hard questions about how it is, exactly, that we "administer race"; we cannot avoid having explicitly to determine and defend how it is we ask public authority to take account of racial identity.

\section{A. Malone v. Haley-Pressure on the System}

This Article attempts to address two closely related questions. How is the law to define the nature and boundaries of the groups utilized in the administration of remedial preferences for persons "on the basis of ... their membership in a specified group or groups"?" How can the law accurately sort individuals into these categories? Thankfully, it has been many years since respected thinkers were producing biologically-determinist rationalizations and typologies for the rigid classification of mankind into racial groups possessing distinct and enumerable physical, moral, and intellectual attributes. ${ }^{2}$ With more wisdom today, we are able to recognize racial and ethnic categories as largely socially-constructed creations. Such categories are at most only stereotypically associated with particular phenotypical characteristics, which are theniselves mutable and, as the Reverend Martin Luther King, Jr. so memorably put it, of no nore intrinsic moral value than the color of one's eyes. That modern Anierican preferential programs are targeted at categories with such a "socially constructed" character makes it even more important-and difficult-to consider carefully the procedures with which we administer race.

The case of Malone $v$. Haley, ${ }^{3}$ an unreported single-justice opinion of the Supreme Judicial Court of Massachusetts, illustrates some of these conundrums. Paul and Philip Malone, twin brothers who lived in Milton, Massachusetts, took part in 1975 in a city civil service competition for jobs with the Boston Fire Department. They scored poorly and were not accepted. The twins, who were fair-haired and light-skinned, ${ }^{4}$ had identified themselves as White in the 1975 test application. In 1977 they tried again, this time identifying thenıselves as Black. The Boston Fire Department had by that time become subject to a court-ordered affirmative action program, ${ }^{5}$ under which the city maintained separate minority candidate lists for firefighter vacancies. The twins' 1977 test scores of 57 and 69 , respectively, would not have qualified them for the job as White candi-

1. James E. Jones, Jr., The Genesis and Present Status of Affirmative Action in Employment: Economic, Legal, and Political Realities, 70 Iowa L. Rev. 901, 903 (1985).

2. See, e.g., Jos. A. Roberts, The Race Conflict in Southern States: An Ethnolocical StUdy of the ORIGINAL Types aNd the EFFect of Hybridity (1899).

3. No. 88-339 (Sup. Jud. Ct. Suffolk County, Mass. July 25, 1989).

4. Id., slip op. at 17-18.

5. Id. at 2 ("[T]he Boston Fire Department [was] subject to a federal consent decree entered in 1975 in NAACP v. Beecher, C.A. No. 72-3060-F (D. Mass.).”). 
dates, ${ }^{6}$ but based upon their self-identification as Black they were hired and served on the force for ten years. The Malones' troubles began in 1987 when they sought promotion to lieutenant, and the Fire Commissioner noticed that the twims were classified as being "Black." A hearing officer declared that the Malones were not Black and had therefore falsified their 1977 application and examination materials, in violation of state Personnel Administration Rule 3(4)(c). The state's personnel administrator promptly fired the brothers. Noting that the Department had required only racial "self-identification" in 1977, the Malones appealed, arguing that they should still be considered Black by the Department.

Deferring to the "particular domain of the factfinder who had an opportunity to observe the witnesses and to judge their credibility,"7 Judge Herbert Wilkins of the Supreme Judicial Court for Suffolk County, Massachusetts, followed the hearing officer's three-part test for adjudicating claims to racial identity. ${ }^{8}$

[T]lie Malones miglit have supported their claim to be Black[:] (1) by visual observation of their features; (2) by appropriate documentary evidence, such as birth certificates, establishing Black ancestry; or (3) by evidence that they or their families hold themselves out to be Black and are considered to be Black in the community. ${ }^{9}$

Neither Malone brother, Wilkins wrote, met any of these three criteria. To begin with, both had "fair skin, fair hair coloring, and Caucasian facial features."10 The personnel administrator had concluded that "they do not appear to be Black."11 The birth certificates of the Malone brothers and of their parents also showed the Malone family to have been "reported consistently to be White" for three generations. ${ }^{12}$ "Finally, there was no evidence that the Malones identified themselves personally or socially as Blacks," except for the narrow purpose of claiming jobs and promotion in the Fire Department. ${ }^{13}$ Judge Wilkins also found substantial evidence that they "did

6. "The lowest scoring non-minority candidate who was ever certified eligible for appointment based on that examination had a score of $82 . "$ Id. at 2 n.2.

7. Id. at 15.

8. Id. at $\mathbf{1 6 .}$

9. Id.

10. Id. at $\mathbf{1 7 .}$

11. Id. (internal quotation marks omitted).

12. Id. at 18. The parents' birth certificates reported the race of the Malone brothers' grandparents as White, thus "establish[ing] the racial identity for three generations." Id.

Against this evidence the Malones marshalled only a

questionable and inconclusive photograph of a woman they claimed to be Sarah Carroll, their maternal great-grandmother.... [T] [Tere was no reliable mcans of verifying the identity of the woman in the photograph. The Malones offered only their hearsay testimony that they had been told that this is a photograph of their great-grandmother. Moreover, even if the identity of the woman were accepted, the hearing officer found that the photograph itself was inconclusive on the issue of the race of the woman pictured.

Id. at 19.

13. Id. at $19-20$. 
not claim Black status honestly or in good faith," but did so only to take advantage of the Department's minority hiring program. ${ }^{14}$

The Malones' case created a stir in Boston. Fearing an epidemic of false racial claims, one city councilor asked the state attorney general to begin an imvestigation of the Fire Department. ${ }^{15}$ Mayor Raymond Flynn ordered an investigation into the Fire, Police, and School Departments, and by the time Judge Wilkins' opinion came down, eleven firefighters were under investigation on similar grounds. ${ }^{16}$

\section{B. Bright Lines and Fuzzy Concepts}

The case of the "Mixed-Up Malones"17 illustrates sone of the minefields that may develop where resources are allocated to people on the basis of their membership in a particular group. Judges and administrators are less fortunate than social scientists: they must at some point draw lines between rival claimants, rewarding one and sending the other home emptyhanded. However analytically "soft" a particular classification may be, making it a centerpiece of governmental resource-allocation will require that it be "hardened" dramatically. ${ }^{18}$ It is this aspect of group definition and individual classification that forms the subject of this Article.

"[F]igures speak and when they do, Courts histen." 19 Modern anti-discrimination law depends fundamentally upon statistical showings of minority group under-representation. Federal courts have for years used statistics as a means of judging discrimination, ${ }^{20}$ but in recent years the volume and complexity of statistically-grounded litigation have increased enormously. The Supreme Court has recognized that " "[s]tatistical analyses have served and will continue to serve an important role' in cases in which the existence

14. Id. at 20. Wilkins had suggested that the twins' self-identification as Black might have becn permissible "even if they are not Black, [had] they claimed minority status in good faith." Id. at 15. A good-faith self-identification, false or not, might have escaped the prohibition of "fraud." See id. at 6-7. But it could not, presumably, have enabled them to continue to take advantage of "Black" status for promotion purposes. In addition to the Malones' self-identification as White in the $\mathbf{1 9 7 5}$ test, Wilkins cited inconsistencies and evasiveness in departmental personnel surveys and in hearing testimony. Id. at 21-22. Though Wilkins did not mention it in his opinion, the Boston Globe had already reported that the Malones had identified themselves as White in the 1986 Milton Town census. See Bella English, Color Coordinated, Boston Globe, Oct. 12, 1988, at 21.

15. Peggy Hernandez \& John Ellement, Two Fight Firing Over Disputed Claim They Are Black, Boston GLoBe, Sept. 29, 1988, at 29.

16. Peggy Hernandez, Firemen Who Claimed To Be Black Lose Appeal, Boston GLoBE, July 26, 1989, at 13, 14.

17. English, supra note 14.

18. The formulation "hardening soft variables" has been gratefully adopted by the author from Professor Bruce Ackerman of the Yale Law School.

19. Brooks v. Beto, 366 F.2d 1, 9 (5th Cir. 1966), cert. denied, 386 U.S. 975 (1967).

20. See, e.g., Norris v. Alabama, 294 U.S. 587, 590-91 (1935) (considering it to be evidence of discrimination that eligible Blacks comprised $7.5 \%$ of the jury pool and yet not one had ever been called). 
of discrimination is a disputed issue."21 The Supreme Court today generally requires plaintiffs to show a "factual predicate" of considerable detail to substantiate a charge of discrimination. In the statutory context of Title VII litigation, for example, the courts since Griggs v. Duke Power Co. ${ }^{22}$ have permitted prima facie cases of employment discrimination to be shown by statistical evidence that an employment practice has a disproportionately adverse impact upon some protected class, irrespective of discriminatory intent. ${ }^{23}$ "Disparate impact" cases under Title VII have therefore invariably revolved around statistical showings of varying detail-either comparisons of minority representation in the workforce to that in the general population $^{24}$ or, in more recent years, to that in increasingly narrow population sub-samples. ${ }^{25}$ Whatever the relevant population sample, however, employment discrimination is often only provable through statistics:

Once the employment practice at issue has been identified, causation must be proved; that is, the plaintiff must offer statistical evidence of a kind and degree sufficient to show that the practice in question has caused the exclusion of applicants for jobs or promotions because of their membership in a protected group. Our formulations ... have consistently stressed that statistical disparities must be sufficiently substantial that they raise such an inference of causation. $^{26}$

The law thus requires we make very "hard" variables indeed of the comparatively "soft" notions of race and ethnicity. Similarly detailed factual predicates are required in voting rights cases as well. City of Mobile $v$. Bolden ${ }^{27}$ required that a demonstrable discriminatory "purpose" be shown in cases arising under the Voting Rights Act of $1965 .{ }^{28}$ Congress, fearing that this new rule might miss discrimination that was "masked and concealed,"29 amended section 2 of the Act in 1982 to make it clear that a

21. International Bhd. of Teamsters v. United States, 431 U.S. 324, 339 (1977) (modification in original) (quoting Mayor of Philadelphia v. Educational Equality League, 415 U.S. 605, 620 (1974)).

22. 401 U.S. 424 (1971).

23. Id. at 432 .

24. See, e.g., Crockett v. Green, 388 F. Supp. 912, 917 (E.D. Wis. 1975) ("A substantial disparity between the proportion of minorities in the general population and the proportion in a specific job classification is sufficient to establish a prima facie case of discrimination.").

25. See, e.g., Wards Cove Packing Co. v. Atonio, 490 U.S. 642, $651-52$ (1989) (requiring showing of data on labor pool of "qualified" individuals); Watson v. Fort Worth Bank \& Trust, 487 U.S. 977,997 (1988) ("[S]tatistics based on an applicant pool containing individuals lacking minimal qualifications for the job would be of little probative value."); New York City Transit Authority v. Beazer, 440 U.S. 568, 585-86 (1979) (requiring data showing racial composition of Transit Authority employees and applicants participating in methadone programs, not merely the racial composition of the New York area methadone-using population).

26. Watson, 487 U.S. at 994-95.

27. 446 U.S. 55, 66-68 (1980).

28. Pub. L. No. 89-110, 79 Stat. 437 (codified at 42 U.S.C. $\S \S 1971,1973-1973$ p (1988)).

29. H.R. ReP. No. 227, 97th Cong., 1st Sess. 31 (1981). 
finding of discriminatory purpose was no longer required. ${ }^{30}$ Since this amendment, findings of discrimination in Voting Rights cases have revolved almost exclusively around statistical evidence. A Congressional list of suggested "typical factors" relevant to judicial findings of section 2 violations, ${ }^{31}$ for example, included several whicl would be nonsensical without a clear means of delineating population group boundaries with great precision: the presence of racially polarized voting, continuing minority disadvantages in various spheres, ${ }^{32}$ the unresponsiveness of elected officials to the particularized needs of minority groups, ${ }^{33}$ and the repeated electoral failure of the "chosen representative[s] of a particular racial group." 34 The post-1982 "results" standard of Voting Rights Act litigation thus also places a great burden upon classificatory procedures. ${ }^{35}$

Assuming that identifying discrimination is unproblematic, what happens once discrimination has been found? Whatever the specific reınedies adopted, ${ }^{36}$ we still require some coherent understanding of who precisely is to be helped, and why. If, as with so-called "victim-identification orders"37 in Title VII enforcement, particular victims of discrimination can be identified, the remedy-directing answer may be straightforward. Harder ques-

30. Voting Rights Act Amendments of 1982, Pub. L. No. 97-205, 96 Stat. 131 (codified at 42 U.S.C. $\S \S 1971,1973-1973 a \mathrm{aa}-6$ (1988)).

31. S. REP. No. 417 , 97th Cong., 2d Sess. $27-29$ (1982), reprinted in 1982 U.S.C.C.A.N. 177 , 204-07. See also generally Frank R. Parker, The "Results" Test of Section 2 of the Voting Rights Act: Abandoning the Intent Standard, 69 VA. L. REv. 715 (1983).

32. S. REP. No. 417, at 28-29, reprinted in 1982 U.S.C.C.A.N. at 206.

33. S. REP. No. 417 , at 29 , reprinted in 1982 U.S.C.C.A.N. at 207.

34. Thomburg v. Gingles, 478 U.S. 30, 68 (1986) (Brennan, J., plurality opinion). For a discussion of the relevance of the race of the "chosen representative," see generally Sushma Soni, Defining the Minority-Preferred Candidate Under Section 2, 99 YALE L.J. 1651, 1656-58 (1990).

35. Measurements of polarized voting, for example, have been held to require the use of sophisticated statistical techniques, such as "Pearson coefficients," often analyzed with the help of expert witnesses. Pearson coefficients are used to help measure the correlation of the percentage of a group registered in a precinct with the precinct vote for candidates from that group. See Robert Bames, Comment, Vote Dilution, Discriminatory Results, and Proportional Representation: What ls the Appropriate Remedy for a Violation of Section 2 of the Voting Rights Act? 32 UCLA L. REv. 1203, 1238-40 \& n.164 (1985). The use of "expert witnesses" in voting rights cases may allow the introduction of more conventional social science data built up from public opinion surveys and other sources which frequently employ racial and ethnic self-identification. The raw information in such cases may thus be more theoretically consistent than that in Equal Employment Opportunity (EEO) applications, and more directly comparable to census-derived base population data. To the extent, however, that voting pattern investigations may implicate the race of candidates themselves, absent clcar self-declaration on the part of candidates for office, there may remain an EEO-style apples-and-oranges data problem of correlating voter self-identification with stereotype-conditioned candidate classification.

36. See generally Eric Schnapper, The Varieties of Numerical Remedies, 39 Stan. L. Rev, 851, 874-912 (1987).

37. With the "victim-identification orders" remedy, victims are identified and given specific remedial measures (job placement, "front pay" until a vacancy, etc.). See id. at 893; see also, e.g., Ivey v. Western Elec. Co., 23 FaIR Empl. Prac. CAS. (BNA) 1028, 1033-35 (N.D. Ga. 1978) (setting up criteria for victim identification and outlining remedies given to identified victims). 
tions arise with "indirect victim,"38 "procedure-neutralization,"39 and "compliance" 40 orders, and in any other circumstances in which there is no close correlation between personal disadvantage at the hands of a particular defendant and gaining advancement througlı a legal remedy directing that defendant to undertake particular employment practices. In such cases, group-specific targeting might be felt an appropriate proxy for "real" disadvantage, or might be adopted on the strength of an assumed connection between group membership and other social wrongs of the general sort in question. In either case, a clear and coherent idea of "group" is necessary-particularly when even "benign" race-based classifications are subject to the exacting equal protection requirements of "strict scrutiny."41

\section{The Easy Cases: Sex Classification and Native American Law}

In drawing distinctions between individual human beings, certain tasks are easier than others. In the context of "affirmative action" and other preferential programs, the easiest differentiating principle to discuss or admimister is sex. In this area, human beings come only in two biological flavors, each fairly easily distinguished by a characteristic chromosomal pattern of $\mathrm{XX}$ (female) or XY (male). Chromosome sets suclı as XXY can occur, but they are quite rare. For the most part, the male/female dicliotomy is one of conceptual clarity. To the extent that society discriminates against women as women, the enormously close correlation between $\mathrm{XX}$ chromosomes and female secondary sexual characteristics (the operative means of distinguishing the sexes and thus presumably of allocating discriminatory harm) ensures that preferential programs for women link remedy to wrong rela-

38. With discrimination which results in indirect victims, an "indirect victim order" places minorities directly into positions in an organization. See Schnapper, supra note 36, at 901-10.

39. Firms may be ordered to increase the number of minorities in particular jobs to eliminate the discriminatory impact of past practices. See id. at 883-88.

40. "Compliance orders" require firms to establish non-discriminatory standards for hiring and/or promotion. Id. at 876-82. Until this is done to the court's satisfaction, a certain percentage of jobs or promotions must be given to minority group members. Id.

41. The Fourtecnth Amendment guarantees to all persons the "equal protection of the laws." U.S. CoNST. amend. XIV, §1. State laws employing racial classifications are judged for equal protection purposes by the application of strict scrutiny. See, e.g., Wygant v. Jackson Bd. of Educ., 476 U.S. 267, 273 (1986) (plurality opinion) (" "Racial and ethnic distinctions of any sort are inherently suspect and thus call for the most exacting judicial examination.' " (quoting University of Cal. Regents v. Bakke, 438 U.S. 265, 291 (1978) (Powell, J.))). More recently, in City of Richmond v. J.A. Croson Co., 488 U.S. 469 (1989), five justices agreed that Richmond's 30 percent set-aside of city contracts for racial minorities did not mect the exacting standards required of suspect classifications. See also Burt Neuborne, Notes for the Restatement (First) of the Law of Affirmative Action: An Essay in Honor of Judge John Minor Wisdom, 64 Tul. L. REv. 1543, 1550-51 (1990) (noting the Court's unease with plans that seem to force a non-discriminating non-minority third party to surrender a settled or an earned employment status). In Shaw v. Reno, $113 \mathrm{~S}$. Ct. 2816 (1993), a congressional redistricting plan in North Carolina which created an elongate district apparently designed solely to ensure a black majority therein was challenged under equal protection. The Supreme Court held that such race classifications are so constitutionally suspect as to "require careful scrutiny under the Equal Protection Clause regardless of the motivations underlying their adoption.". Id. at 2826. 
tively cleanly. This neat fit might not be absolute, but the classificatory criteria of sex-based differentiation permit a fairly consistent, coherent, and empirically manageable standard. ${ }^{42}$ Insofar as there are biological and physiological differences between the sexes as a result of chromosomal allotments, affirmative action programs premised upon the need to achieve population-proportionality by gender may remain controversial, at least in some fields. ${ }^{43}$ The biological grounding of sexual differentiation, however, ensures that it is still possible to talk meaningfully about legal group differentiation for purposes of adjudicating the merits of claims to group-based benefits. If Paul and Philip Malone had claimed to be women for purposes of promotion, the disposition of their case would not have been so awkward.

The legal tasks of delineating other populations vary considerably in difficulty. The peculiar history of the Native Americans' absorption into the.United States makes it possible, with little difficulty, to classify members of Native Anerican tribes for purposes of defining the jurisdiction of tribal courts. As will be seen below, the "political" status of the designation "Indian" in the U.S. context - the result of tribes' ostensibly "negotiated" incorporation into the U.S. constitutional system-makes defining individual tribe members (at least in theory) a comparatively easy task. In contrast to the straightforward biological dicliotomy of human sexual classification, the distinction between a Native American and a person of English descent, for example, cannot be conclusively determined scientifically. However, since the definitional category of "Indian" is not scientific but is expressly "political," no incoherence results from leaving demarcation to "political" decisions by "politically"-recognized tribal units holding their quasiindependent constitutional status by a process of bargaining with the U.S. government. The problen with group classifications arises where the categories enuployed are neither genuinely "objective" (i.e., scientifically determinable) nor susceptible to legitiniation by reference to a decision-making entity (such as a Native American "tribe") whose authority to make such decisions is unquestioned.

42. Not everyone would agree that the sex classification problem is so simple. However, such a discussion is beyond the scope of this Article. For a discussion of the complexities of categorizing people according to sex and gender, see Frank Valdes, Queers, Sissies, Dykes, and Tomboys: Deconstructing the Conflation of "Sex," "Gender," and "Sexual Orientation" in Euro-American Law and Society, 82 CALIF. L. REV (forthcoming Dec. 1994). For the purposes of this Article, it is clear that classifying according to sex is an easier task than classifying according to race.

43. The work of some evolutionary biologists on sex-linked behavioral and developmental differences between males and females has sparked much controversy and debate over the meaning of equality and the legal import of sexual differentiation. See, e.g., Kingsley R. Browne, Biology, Equality, and the Law: The Legal Significance of Biological Sex Differences, 38 Sw. L.J. 617 (1984) (citing studies of the influenee of male and female hormones on behavior). 


\section{The Muddiness of Race}

This is precisely the difficulty with the categories of "race" and "ethnicity." While sex is (arguably) a dichotomous variable, race is nothing of the sort. "[B]iologically it is a continuous variable, or, to be precise, a series of variables, most of which are continuous. A person's racial identity is largely a social phenomenon, rather than a biological one."44

If the various human "races" were different species, their differentiation and classification would be much more manageable. While different species cannot breed with each other, humans invariably do-and the phenotypical characteristics we traditionally associate with particular "races" are not quanta of racial identity but infinitely modulated characteristics which further shade into each other with each successive umion. Indeed, the criteria for "racial" differentiation themselves are but socially-conditioned ones: in biological terms can we say with certainty that George Wallace is more "different" from Stokely Carmichael than Carmichael himself is from Siad Barre? And if "racial" differentiation seems problematic, what are we to make of "ethnic" identity, in which a host of indefinable cultural, educational, and environmental factors complicate these already-muddy waters? As one scholar provocatively put it, "[M]ost native-born U.S. Negroes far from being nonwhite, are in fact part white. They are also by any meaningful definition of culture, part Anglo-Saxon, and they are overwhelmingly Protestant." ${ }^{45}$ However strongly racial and ethnic differences may be perceived, and however "real" they may be insofar as they powerfully affect the lives people lead, can they be pinned down with the conceptual coherence and replicability that group-oriented benefit allocation requires?

There exist two basic approaches to this classificatory task:

(1) Self-reported identity-individuals are asked to assign themselves a racial identity based upon the particular group with which they most closely identify or of which they otherwise feel a part; and

(2) "Other-ascribed" identity-individuals are placed into categories according to the perceptions of their racial or ethmic identity held by a designated decision-making third party. An individual's membership in a particular group might thus be determined according either to

(a) Member reference - whether or not members of that group (however defined) consider her to be a fellow member, or

(b) Nonmember reference-whether or not nonmembers of that group consider her to be a member of that group.

44. Id. at 666-67 (footnote omitted).

45. Yehudi O. Webster, The Racialtzation of America 144 (1992) (quoting Albert Murray, The Omni Americans: New Perspectives on Black Experiences and American Culture $79-80(1970))$. 
It seems to be taken for granted in modern American racial jurisprudence that these categories are coterminous. For gender-based classification, this may be true: one would not, in most cases, expect divergence between someone's self-perceived identity as a male, on the one hand, and the agreement of either men or women about this fact of biological identity, on the other. With respect to racial and ethnic characterizations, however, this cannot so easily be said to be true. Therefore, these classification schemes may produce different results. If racial and ethnic identity is to remain a salient factor in the allocation of social benefits, we must be aware of how various procedural systems may. differ; we must be willing to examine the degree to which the pohicy imterests served by each such classification scheme map the contours of sociological identity. The proper procedure for "administering race" is the core dilemma of moderu raceconscious law.

The race-administration systems examined below employ these classification paradigms in different mixtures and take them to different extremes. Part II of this Article will examine the ways in which this task is presently approached in the United States for various purposes, while Part III will recount other significant approaches to racial or ethnic classification taken, for comparative purposes, from other areas of law, from U.S. history, and from other countries.

II

\section{ADMINISTERING BENEFITS}

At present, the two primary U.S. systems for group-keyed benefit allocation are the promulgation and enforcement of anti-discrimination laws such as those requiring proportional hiring and promotion, and the redrawing of political boundaries on the basis of race so as to create "minoritymajority" districts that will boost minority political representation in local, state, or national political fora.

\section{A. Employment: The EEOC and Affirmative Action}

The first modern "affirmative action" program was established in 1969, when the U.S. Department of Labor issued the "Philadelphia Plan" to set up racial hiring goals and tinietables for contractors involved in federally-assisted construction projects in that city. ${ }^{46}$ Since then, a network of federal regulations has been put in place requiring federal contractors, pri-

46. For a description of the Philadelphia Plan's hiring goals, see Owen M. Fiss, A Theory of Fair Employment Laws, 38 U. CH1. L. Rev. 235, 274-75 n.49 (1971). An account of the policy roots of affirmative action appears in Jones, supra note 1, at 905-07, and James E. Jones, Jr., The Origins of Affirmative Action, 21 U.C. DAvis L. REv. 383, 393-94 (1988). Another early approach simply imposed hiring goals on building contractors by requiring alternating Black/White job referrals. See Local 53 of the Int'1 Ass'n of Heat and Frost Insulators v. Vogler, 407 F.2d 1047, 1051 (5th Cir. 1969). This was said to work well as a preliminary injunctive measure because the demand for referrals was then high. See Fiss, supra, at 275 n.49. 
vate employers, public school systems, institutions of higher education, the armed forces, and various organs of local, state, and federal government to implement anti-discrimination measures of various sorts. An important part of such regulation has been to require racial and ethnic ${ }^{47}$ group-based preferences in hiring and promotion decisions, in an effort to make up for past discrimination suffered and to overcome disadvantages "built in" to American society by a legacy of historical and ongoing wrong. ${ }^{48}$ The success of this remedial effort relies upon the existence of the discrete and definable classification categories that are its stock in trade. ${ }^{49}$ If benefits are to be provided to people "on the basis of . . their membership in a specified group or groups," 50 the law must have some clear and coherent way of identifying groups and group members. Whenever there are "Malones" willing to challenge their allocated position in a benefit-distribution scheme, the system must be willing to examine its foundations.

Preferential programs rely for their coherence upon making hard numbers out of the conceptually muddy-i.e., "soft"-variable of racial identity. Given that the pervasive ethno-racial cost-accounting of government policy relies inescapably upon detailed statistical data, where does this information come from? In the employment context, the group-keyed allocation of benefits for purposes of "affirmative action" is derived from two very different sources of information. The first of these is the U.S. Census and the various population projections derived from it. The second is the information provided by employers through their Equal Employment Opportunity filings as mandated by federal law. We shall examine each of these in turn.

47. No attempt will be made here to define the terms "race" and "ethnicity," primarily because this Article argues that they are ultimately indefinable. As terms denoting vague (but tenaciously held) concepts of collective biological and/or cultural identity, however, their use is unavoidable.

48. Central to affirmative action theory is the idea of remedy, necessarily conceived in group terms. Discrimination "is not ... against individuals. It is discrimination against a people. And the remedy, therefore, has to correct and cure and compensate for the discrimination against the people and not just the discrimination against the identifiable persons." Burke Marshall, A Comment on the Nondiscrimination Principle in a "Nation of Minorities," 93 YALE L.J. 1006, 1006 (1984). In "confer[ing] benefits upon a class of persons, namely, the actual and likely victims of discrimination," Fiss, supra note 46 , at 236 , remedial preference programs hope to achieve a "transitional compensation for past wrongs" by putting entire racial or ethnic groups in a socio-economic position that is the "rough equivalent of proportional representation," Marshall, supra, at 1011-12. This means returning the victims to the position where they would have been "but for discrimination." Jones, supra note 1, at 921.

49. The modern American commitment to remedial group-keyed racial benefit-allocation is predicated upon certain assumptions about the salience and coherence of racial and ethnic identity, both in the allocation of social disadvantage and in its correction. "The model of justice underlying affirmative action is characterized by two basic elements: (1) use of a racial preference to include or exclude, and (2) reliance on the group as its fundamental entity." Arval A. Morris, New Light on Racial Affirmative Action, 20 U.C. DAvis L. REv. 219, 227 (1987).

50. Jones, supra note 1 , at 903 . 


\section{The National Census}

In the final account, it is the Bureau of the Census that tells us the most, in aggregate terms, about our collective racial and cultural heterogeneity. Race and ethnicity statistics are compiled from three different questions on the basic census data forms sent to households around the country every ten years. The most significant aspect of this information is that it is entirely self-reported. Question 4 on both the "long" and "short form" questionnaires deals with the race of individual respondents. While sex, age, marital status, and other questions are asked as siniple factual responses, each respondent is asked to fill in one of several circles indicating "the race that the person considers himself/herself to be." However Question 7, regarding respondents' "Hispanic origin," is an inquiry demanding a rather less subjective answer: "Is this person of Spanish/ Hispanic origin?" A handful of permissible responses are offered..$^{52}$ Question 13 appears only on the "long form" sent out to seventeen percent of households nationwide, and asks, "What is this person's ancestry or ethnic origin?"53 A number of suggested answers are provided for Question 13, largely pertaining to non-U.S. national origin. ${ }^{54}$ Questions 4,7 , and 13 are asked independently, and no relationship of nutual exclusivity exists among any of their responses. ${ }^{55}$ These responses form the raw data from which the Bureau of the Census compiles its elaborate accounting of America's racial and ethnic heterogeneity and ethnographic trends. As is evident from the self-conseiously subjective "race that the person considers himself/herself to be" query of Question 4, the Census Bureau disclaims any pretense of objective "reality"-though in the wording of Questions 7 and 13 it approaches the various indices of ethnic and cultural origin with less relativist qualification. Self-reported census data relies upon respondents returning "accurate" answers in all areas, of course, but these categories of race and ethnicity are analytically "slippery" in a way that indicia of income and marital status are not.

A inajor technical problent for the census compilers is that this selfreported data is frequently incomplete. There is no way to compel responses to all sections, and no way to ask follow-up questions later. Furthermore, with the addition of write-in "Other API" (Asian/Pacific

51. Bureau of the Census, U.S. Dep't of Comm., Official 1990 U.S. Census Form D-61, at 2 (1989) (emphasis added).

52. Id.

53. Id. at 6.

54. Id.

55. The form permits, for example, a racial response of "Eskimo" and a simultaneous Hispanic origin answer of "Argentinian." Question 13 is also asked independently, permitting an Argentinean Eskimo to indicate her Nigerian ancestry-and since Question 8 on the long form asks respondents to indicate their U.S. state or foreign country of birth, a single person might, for example, cntcr a procedurally valid self-reported response of Eskimo (race), Argentinian (Hispanic origin), Nigcrian (ancestry/ethnicity), and Ukrainian (national origin). 
Islander) and "other Spanish/Hispanic" categories since the 1980 census, ${ }^{56}$ data-collectors receive a barrage of idiosyncratic responses. Nearly ten million people coded the "other race" box on the 1990 census forms, either inarking the "other" circle without elaboration or writing-in a different group name. Some of these responses were routinely folded back into the standard categories ("African-American," for example, was assigned to the "Black or Negro" classification), but many "other" categories did not so easily fit. For some statistical purposes "other" answers could be left as they were, but for other purposes (such as projecting yearly group population data until the next census) the existence of these "non-specifieds" was considered unacceptable: ${ }^{57}$

The existence of this group is inconsistent with the race categories defined by the Office of Management and Budget in OMB Directive 15. Such "non-specified" race persons also are not found in data sources other than the census. In order to serve the needs of some portions of the [data] user community it is necessary to assign each of these persons to a specified race..$^{58}$

Because ninety-five percent of the "other race" responses were found to be write-ins of apparent Hisparic sub-groups, ${ }^{59}$ the Bureau used a "Race Assignment Rule" which assigned each non-specified respondent "to the specified race reported by a nearby person with an identical response to the Hispanic origin question." 60 Nonresponders were classified as being of the same race as their nearest family member, housing-bloc co-resident, and so forth. Those who did not indicate an ethnic origin were themselves assigned that of the person in the nearest "proximity."61 This "raceinodification" system allowed the 9.8 million "other race" respondents to be folded back into the standardized categories of Question $4 .^{62}$ This had some effect upon the aggregate population totals recorded for the country, increasing, for example, the number of recorded "Whites" by about nine million, "Blacks" by about 500,000, and "Asian/Pacific Islanders" by just under $200,000 .{ }^{63}$

56. American Demographics, 1990 Census Questionnatre 2 (1989) (available from Bureau of the Census, U.S. Dep't of Comm.).

57. Telephone Interview with Stanley Rolark, Racial Statistics Office, National Bureau of the Census (Mar. 11, 1993).

58. Gregory Spencer, U.S. Dep't of Commerce, No. 1990 CPH-L-74, Age, Sex, Race and Hispanic Origin Information from the 1990 Census: A Comparison of Census Results with Results Where Age and Race Have Been Modified 1 (1991).

59. Id. at 2.

60. Id. at 1.

61. Telephone Interview with Gregory Spencer, Chief of the Population Projections Branch, National Bureau of the Census (Mar. 11, 1993).

62. SPEnCER, supra note 58 , at 1 .

63. Raw total population figures appear in id. app., tbl. 2, at 7-12. The "race-modified" totals appear at id. app., tbl. 1., at 1-6. 
Interestingly, persons reporting themselves to be American Indians but not listing an officially-recognized tribe were excluded from the statistical "race-modification" process because

preliminary 1990 research suggested questionable reporting in the American Indian category and ... previous research showed that a high proportion of such persons were much less likely to be American Indians than those, who actually provided a specific tribe response as instructed on the census form. ... These were excluded because of evidence from the 1980 census that misreporting of race was mucl higher in thèse codes than it was in codes representing specific American Indian tribes. ${ }^{64}$

Additionally, the results of race-modification procedures were overridden in four U.S. counties where they resulted in what was deemed to be too large a modification-driven increase in the listed American Indian population: "In each [such] case the persons were made White." 65 This kind of race-modification override based on the Bureau's independent assessment of whether individuals in question were "really" of the race they claimed themselves to be was apparently only possible for the Native Americans due to the peculiar status of "Indian" under U.S. law. For other self-identified racial and ethnic categories no such quasi-empirical "verification" was possible.

Even apart from "race modification" procedures that reclassify the given response of nearly one American in twenty-five, ambiguity lurks in the contingent nature of any self-reported system for racial and ethnic classification, such as the U.S. census. Personal self-identification, after all, is enormously contextual: "It embraces multiple levels or tiers, and it changes with the environment. An African student in France will identify himself in one way; at home, in another. . . . Notwithstanding the multiplicity of ascriptive identities, all levels do not remain equally significant, if only because all contexts do not remain so." ${ }^{.66}$ Since race and ethnicity are socially-constructed categories, they may vary over time and from place to place. For example, José Cabranes has recounted the confusing attempts to apply conventional "North American notions of race" to the population of Puerto Rico during the early years of the 20 th century. ${ }^{67}$ Put simply, the problem was that Puerto Ricans and the mainland census administrators and interpreters had very different concepts of "race." It was frequently observed in this regard that " on the mainland a drop of Negro blood

64. Id. at 2.

65. Id. at 3.

66. Donald L. Horowitz, Ethnic Identity, in Ethnicity: TheORY AND ExperienCe 111, 118 (Nathan Glazer \& Daniel P. Moynihan eds., 1975) (footnote omitted).

67. See José A. Cabranes, Citizenship and the American Empire (1979). 
makes a white man a Negro; while in Puerto Rico a drop of white blood makes a Negro a white man." "68

Since self-reported data from the island assumed one "definition" of race while mainland data-interpretation assumed another, official U.S. government statistics for Puerto Rico, writes Cabranes, "were invariably meaningless." ${ }^{69}$ As a result of the incompatibility of mainland and Puerto Rican conceptions of race, U.S. census reports between 1899 and 1950 suggested that blacks and mixed-race persons were simply vanishing, as the percentage of the population (self-)reported as "White" increased steadily with each decade of U.S. governance. This "disappearance" became so marked by 1939 as to prompt a major American encyclopedia to remark that

[i]f this decrease should continue for a number of years, the black race would eventually disappear from Porto Rico [sic] unless there is an immigration of that race from the other West Indian islands in the future. This is the only island in all the West Indies where the white population is so overwhelmingly in the majority. ${ }^{70}$

The number of people whom mainlanders might classify as "Black" may have been no fewer than before-or indeed might have actually increased-but because the idiosyncratically self-reported census data shared no benchmark of "real" racial identity with its interpreters, the mainlander and the Puerto Rican eacl ended up with an inaccurate statistical account of the other.

The salience attached to particular characteristics and the classificatory meaning of such attributes thus may be quite malleable. Particularly in a system of self-reported identity that allows intuitively anomalous responses, such as the U.S. census, and which routinely "modifies" millions of personal identifications, the degree to which census information can be said to reflect the "true" racial composition of the population is questionable. From the abstract theoretical vantage point of the Census Bureau, it is difficult to judge the degree to which different self-reporting individuals and subpopulations may be "speaking" in mutually unintelligible classificatory tongues.

\section{Employer EEO Filings}

Of all classification systems in the United States, race classification carried out through Equal Employment Opportunity (EEO) regulations and the group-preferential hiring and promotion policies of affirmative action programs has perhaps the most immediate impact on American lives. The government has been unable to provide much definitional help to the

68. Id. at 98 n.475 (quoting PUerto Rico Reconstruction Admin. In COOPERATION with the Writers' Program of the Works Prooress admin., Puerto Rico: A Guide to the Island of BORIQUÉN 110 (1940)).

69. Id.

70. 22 Encyclopedia Americana 403 (1939), quoted in Cabranes, supra note 67, at 98 n.475. 
administrators of such programs, however. The Department of Labor's EEO rules for federal contractors, for example, included "Standard Federal Equal Employnent Opportunity Construction Contract Specifications," which defined "minority" by describing various racial groups merely as "having origins in" or as the "original peoples" of various continents (Africa, Europe, Asia, the Americas). ${ }^{71}$ Despite the indeterminacy of these definitions, the failure of federal contractors to apply specified minority hiring goals may result in the termination of an employer's federal contracts, and debarment from future contracts. ${ }^{72}$ Under Title VII of the Civil Rights Act of 1964,

every employer, eniployment agency, and labor organization subject to this title shall (1) make and keep such records relevant to the determinations of whether unlawful employment practices have been or are being committed, (2) preserve such records for such periods, and (3) make such reports therefrom, as the Commission shall prescribe by regulation or order $\ldots .^{73}$

Federal district courts are given jurisdiction to enforce compliance upon the application of the Equal Employment Opportunity Commission (EEOC) or the U.S. Attorney General. EEO record-keeping requirements expressly

supersede any provision of State or local law which may conflict with them. Any State or local laws prohibiting inquiries and recordkeeping with respect to race, color, national origin, or sex do not apply to inquiries required to be made under these regulations and under the instructions accompanying [EEO] Reports . . . ${ }^{74}$

An EEO-1 form detailing employment by race, ethnicity, and sex is required of most private employers subject to Title VII. ${ }^{75}$ Similar require-

71. 41 C.F.R. $\$ 60-4.3(\mathrm{a})$ (1)(d) (1993). For these purposes the federal authorities, unlike census and vital statistics officials, make no effort to distinguish between race and ethnicity. However, the definitions are still not wholly mutually exclusive: while "Black" is defined expressly to exclude individuals of Hispanic origin (a departurt from census and vital statistics methods), Hispanic minorities are still said to be defined "regardless of race." Asians and Native Americans, however, are not defined so as to exclude Hispanics. Further muddying these definitional waters, the EEO regulations also require federal contractors to keep records of "Blacks, Spanish-surnamed Americans, American Indians, and Orientals" in their employ. 41 C.F.R. $\$$ 60-2.11(a) (1993) (emphasis added).

72. The standard form sent to all private employers required to submit filings to the Equal Employment Opportunity Commission (EEOC) informs the employers of the consequences of their failure to comply with EEO regulations. See EEOC, STANDARD FORM 100, Rev. 4-92, EMPLOYER INFORMATION REPORT EEO-1: INSTRUCTION BOOKLET 1 (1992) (referring to the sanctions under $\S 209$ (a) of Executive Order 11246) [hereinafter STANDARD Form 100].

73. Title VII, Civil Rights Act of 1964, Pub. L. No. 88-352, $\S 709$ (c), 78 Stat. 241, 262 (codified as amended at 42 U.S.C. $\$ 2000 \mathrm{e}-8$ (c) (1988)).

74. 29 C.F.R. $\S 1602.29$ (1993) (covering recordkeeping requirements for labor unions); see also 29 C.F.R. $\$ 1602.30$ (1993) (requiring similar recordkeeping by state and local governments); 29 C.F.R. $\S 1602.39$ (1993) (requiring similar recordkecping for public primary and secondary schools).

75. Standard Form 100 , supra note 72 , at $1, \S 1$ (A) (explaining who must file a EEO-1 Form). Willfully making a false statement on an EEO-1 form is defined as a violation of 18 U.S.C. $\$ 1001.29$ 
ments for filing forms obtain for labor unions subject to Title VII (EEO$3),{ }^{76}$ state and local governments (EEO-4), ${ }^{77}$ public schools (EEO-5), ${ }^{78}$ and institutions of higher education (EEO-6). ${ }^{79}$

Self-reported information provided by employers on the race, ethnicity, and sex of their employees (broken down by job category) is used to evaluate their compliance with federal hiring goals. The Department of Labor runs a nationwide network of Office of Federal Contract Compliance Programs (OFCCP) offices which draw up statistical tables showing workforce availability by race, sex, job category, and skill level. These Metropolitan Statistical Area (MSA) and other regional tabulations are the standards against which hiring practices are judged for federal contract compliance and Title VII "disparate impact" purposes. The proportion of women and minorities employed in each "job group" is compared to calculations of the theoretical availability in the local labor market of each category of person with the appropriate skill level. A finding of "underutilization," which occurs when a job group has "fewer minorities or women . . . than would reasonably be expected by their availability,"80 requires an employer to work out a suitable remedy with the local regulatory bureaucracy. ${ }^{81}$ OFCCP rules do not give precise standards for judging underutilization, but three basic approaches are possible.

One approach is the "any difference" standard. If there is any difference between relevant group proportions employed and those available in the local labor market, then the group is "underutikzed." This approach

C.F.R. $\$ 1602.8$ (1993). It is punishable thereunder by a fine of up to $\$ 10,000$ and imprisonment for up to five years. 18 U.S.C. $\$ 1001$ (1988).

76. 29 C.F.R. $\$ \S 1602.22-28$ (1993); see also EEOC, EEOC FORM 274, LOCAL UNION REPORT (EEO-3): INSTRUCTIONS FOR FiLING AND ReCORDKEePING ReQUIREMENTS 1 (1993) [hereinafter EEOC FORM 274].

77. 29 C.F.R. $\$ \$ 1602.30-.38$ (1993); see also EEOC, EEOC ForM 164, STATE AND LOCAL GOVERNMENT INFORMATION (EEO-4): INSTRUCTION BOOKLET 1-2 (1991) [hereinafter EEOC FORM 164].

78. 29 C.F.R. $\$ \S 1602.39-.45$ (1993); see also EEOC, EEOC Forms 168A AND B, ELEMENTARYSeCONDARY StafF Information (EEO-5): Instructions for Filing and RecordkeEping REQUTREMENTS 1 (1992) [hereinafter EEOC Forms 168A \& B].

79. 29 C.F.R. $\$ \S 1602.47-55$ (1993); see also EEOC, EEOC FORM 221, HigHER EDUCATION Stafr INFORMATION (EEO-6): INSTRUCTION BOOKLET 1 (1991). These guidelines refer to the staff members employed by universities; there is no federal oversight of the group composition of the student body at such institutions. Note, however, that in the context, at least, of law school admissions, affirmative action programs are not voluntary: the ABA requires all law schools seeking accreditation (or wishing to keep their accredited status) to "demonstrate, . . . by concrete action, a commitment to providing full opportunities for the study of law and entry into the profession by qualified members of groups (notably racial and ethnic minorities) which have been victims of discrimination in various forms." Standards for Approval of LAw SchOols and INTERPRETATIONs, Standard 212 (American Bar Ass'n Oct. 1992).

80. 41 C.F.R. $\S 60-2.11(b)$ (1993).

81. See generally Basic EEO Resource Manual ch. 16, at 7-16 (Douglas S. McDowell et al., National Found. for the Study of Employment Policy eds., 1989). Federal guidelines to help employers do in-house "workforce analyses" and "utilization analyses" are contained in 41 C.F.R. $\$ \S 60-2.11(\mathrm{a})$ (b) (1993). 
was promulgated in an OFCCP Technical Guidance Memorandum, but has been rejected by several courts. ${ }^{82}$ A second approach would be the "statistically significant" difference standard. If the discrepancy is statistically significant, underutilization is occurring. This approach is suggested in Hazelwood School District $v$. United States. ${ }^{83}$ A possible third approach would be a bright-line mathematical rule. For example, a violation occurs if the level of employment falls below eighty percent of the proportional representation of the group in the local labor market.

Whichever test is used, it is clear that each is subject to classification difficulties. A commercial manual for employers facing the federal compliance audits notes:

Determining [female and minority workforce] availability is a complicated, laborious and time-consuming process. It is inherently subjective in niany respects and the end product represents a rough estimate, at best. It often is a source of conflict during compliance reviews with OFCCP investigators seeking high availability figures by emphasizing population and unemployment figures, and contractors seeking relatively low availability figures by stressing the importance of skills. In the final analysis, availability figures often are more the product of negotiation than they are precise calculation. $^{84}$

Even if "negotiated," however, the compliance process requires some source of raw data.

The Bureau of the Census compiles MSA breakdowns of local occupational categories by sex, Hispanic origin, and race for federal EEO officials from the self-reported sex, race, and ethnicity responses of the "short form" questionnaire and the detailed education and occupational breakdowns of the "long form." 85 The classification procedures for judging employer compliance, however, are quite different. The group definitions suggested to employers generally follow the "original peoples" formulation

82. See, e.g., Firestone Synthetic Rubber \& Latex Co. v. Marshall, 507 F. Supp. 1330 (E.D. Tex. 1981). The "any difference" standard is apparently, however, still urged by OFCCP as a proper standard. See BASIC EEO Resource MANuAL, supra note 81 , ch. 16, at 15 . This test in many cases might well not meet the sort of "manifest imbalance" required in order to justify race-conscious remedies under Johnson v. Transportation Agency, 480 U.S. 616, 628-31 (1987).

83. 433 U.S. 299, 306-13 (1977) (acknowledging that statistically significant differences can make a prima facie case, which is rebuttable by evidence that the statistical difference is not caused by discrimination); see also BAsic EEO Resource MANUAL, supra note 81, ch. 16, at 16.

84. BAsic EEO Resource MANuAl, supra note 81 , ch. 16, at 4.

85. Telephone Interview with Mary Kirk, EEO Statistics Office, National Burenu of the Census (Mar. 10, 1993); see also Bureau of the Census, U.S. Dep't of Comm., 1990 Census EeO File 2 (1992). The Population Estimates and Projections office prepares elaborate projections of population trends and projected population totals on a group-by-group basis for many years in advance. See, e.g., Jennifer C. Day, U.S. Dep't of Comm., Population Projections of the United States, ay Aab, SeX, Race, and Hispanic Orioin: 1992 to 2050 (1992). 
found within federal regulations. ${ }^{86}$ These definitions are not entirely consistent with the Census definitions. While the Census statistics treat Hispanic origin as a category independent of race, ${ }^{87}$ the eniployer guidelines themselves expressly define the "Black" and "White" groups to exclude persons of Hispanic origin. ${ }^{88}$ The Census Bureau tries to resolve this tension between the census and EEO classification by re-counting "Hispanic" as an exclusive category as it compiles MSA statistics from raw census data. ${ }^{89}$

More fundamentally, however, there is a tension between the methods of the census/MSA systems and employer EEO systems of classification. Census-derived data is ultiniately self-reported. Racial and ethnic classifications of employees are seldom so. To begin with, federal EEO compliance officials apparently have no way of "verifying" the figures employers submit in their EEO filings. The law prohibits the use of census data to connect employer responses to individual names, so EEO filing and MSA data cannot be directly linked. ${ }^{90}$ EEO regulations also actively discourage asking employees to classify themselves, and federal compliance officials apparently feel that employee-by-employee self-identification surveys are beyond their capacity. ${ }^{91}$ Compliance audits may check enıloyer EEO reports against the group-classified personnel records eniployers are

86. Standard Form 100 , supra note 72 , at 5 . Other EEO forms use the same categorizations. See, e.g., EEOC FORM 164, supra note 77, at 5; EEOC Form 274, supra note 76, at 2.

87. See StANDARD Form 100 , supra note 72 , at 5 .

88. See, e.g.. EEOC ForM 164, supra note 77, at 5. The EEOC also advises employers that, for classification purposes, "no person should be counted in more than one race/ethnic group." STANDARD Form 100 , supra note 72 , at 5 .

89. In its occupational-category statistic, the Bureau provides only the categories "Hispanic origin" and five racial categories specifically designated "not of Hispanic origin." BUREAU OF tHE CENSUS, supra note 85 , at 2 . This is not wholly consistent with the contractor guidelines and "minority" definitions of 41 C.F.R. $\$ 60-4.3(1)$ (d) (1993), which fail to define the "Asian and Pacific Islander" and "American Indian or Alaskan Native" categories as being exclusive of Hispanic origin. Nonetheless, this procedure avoids some of the practical problems that might be created by comparing data in which Hispanic origin identification removed respondents from the pool of racial identifiers to data in which it did not. The greater apparent formal consistency of the MSA and EEO categories, however, simply changes the locus of disconnection between EEO/MSA classifications and the underlying self-reported census data. The change of Hispanic origin into a race-displacing category from a race-independent one by the MSA compilers presumes that self-identified "Spanish culture or origin" is necessarily a more salient axis of individual self-identification and/or employment discrmination than "color," a conclusion which is not intuitively obvious. Nor is this treatment of Hispanic origin as race-displacing consistently followed even within the Census Bureau's EEO file. "Detailed occupation" and "educational attainment" breakdowns are not compiled in that file with reference to Hispanic origin and thus operate from a proportional population base very different from the employer-reporting system in which the country's nearly 23 million "Hispanic" self-identifiers are counted as a distinct category exclusive of (indeed, carved out of) other racial classifications.

90. Indeed, official census forms are kept scrupulously confidential. Completed census formswhich are the only way of connecting particular racial and ethnic classifications to individual names and addresses-are available only to census officials and only for statistical purposes for the first 72 years after their submission. BUREAU of THE CENSUS, supra note 51, at 1.

91. Telephone Interview with Federal Compliance Officer at the District Office of the U.S. Dep't of Labor, Hartford, Conn. (Mar. 9, 1993). 
required to keep, but cannot systematically "verify" individual classifications. 92 OFCCP audits of employers suspected of "underutilizing" women or minority groups" can include an on-site investigation by an "Equal Opportunity Specialist" (EOS), but if any takes place at all, EOS "verification" of employer-submitted hiring figures is only of the most informal sort, based upon stereotyped group categories and a cursory "visual survey" of employees encountered. ${ }^{94}$ That such impressionistic "verification" may sometimes occur is indicated by the care with which employers often seek to stage-manage EOS on-site visits to show off "units which are fully utilized with women and minorities ... . [and] areas of affirmative action accomplishments."95 As a rule, however, federal auditors rely exclusively upon employer-submitted figures. Compliance is thus evaluated by comparing individually self-reported "availability" data with employer-reported group hiring and promotion figures.

Employer data itself is usually the product of what might be called "intuitive-appraisal tests." If, to the recording official, a person "seems" to be Black (or Hispanic, Asian, etc.) she is classed as so being. The use of employee self-identification for EEO record-keeping (which would be more consistent with MSA data) is permitted, but is strongly discouraged given the "sensitivity" of such inquiries. As an alternative, federal regulators encourage simply making a "visual survey" of the workforce."

92. Telephone Interview with Tony Perkins, Secretary, Equal Opportunity Advisory Council (Mar. 12, 1993); Telephone Interview with Lynwood Battle, Personnel Administrator, Proctor \& Gamble Co. (Mar. 12, 1993).

93. A finding of "underutilization" is not the same thing as a finding of unlawful discrimination. Underutilization cases will usually be settled by agreement with an offending employer without formal litigation.

94. OFCCP officials contacted in the preparation of this Article claimed never to "spot-check" employee self-identification by asking employees what race they considered themselves to be. Moreover, even if this self-identification approach were used it would not produce useful results until a representative sample of the workforce was queried by the EOS.

95. BASIC EEO ResourCe MANUAL, supra note 81 , ch. 17, at 7. The Equal Employment Advisory Council (EEAC) advises its employer-clients to tour their own plants ahead of time "in order to identify areas where the accomplishments of the company's affirmative aetion efforts are the most apparent." Id. (emphasis omitted). A visiting EOS should be taken to those "departments or other organizational units which are fully utilized with women and minorities, and employment offices where all of the required employment notices are prominently posted." Id. The EEAC recommends that employers not allow the EOS "to roam aimlessly throughout the facility." Id. Rather, they should "outline a route in advance which will highlight areas of affirmative action accomplishments." Id. Employers are well advised, the Council writes, to prepare a "strategic plan" for handling EOS inspections: "The purpose of the plan is to manage the activities of the investigator so that he or she develops a favorable impression of the company's affirmative action programs." Id. ch. 17, at 9. The EEAC also recommends that employers attempt to persuade a visiting OFCCP official to commit in advance "to the number and identity of persons to be interviewed." Id. ch. 17, at 12.

96. The EEO-1 instructions, for example, stress that an employer "may acquire the race/ethnic information necessary for this report either by visual surveys of the work force, or from postemployment records as to the identity of employees. Eliciting information on the race/ethnic identity of an employee by direct inquiry is not encouraged." STANDARD Form 100, supra note 72, at 4-5. Similar wording appears in EEOC Forms 168A \& B, supra note 78, at 6. Moreover, 29 C.F.R. § 1602.13 (1993) notes that "Employers may acquire the information necessary for completion of . . . Report EEO- 
The instructions that accompany EEO-3 (a reporting form for unions) describe four possible approaches to employee classification. ${ }^{97}$ The first method, classification based upon "existing records," rehes upon the existence of previous classifications and thus presupposes a prior choice amongst the remaining three options. ${ }^{98}$ The next two approaches are variations on the intuitive-appraisal method: an official may "make a tally of each person by race/ethnic category and sex using personal knowledge and acquaintanceship with the persons listed" or "[a] visual survey, or "lead count' niay be used for identifying individuals by race/ethnic category and sex[,] . . . [which] is usually the simplest way to gather information ... where persons are together in one place." 99

The fourth option is "Self-Identification." 100 As we have seen, however, because of "the high degree of sensitivity of many persons when asked to identify themselves[] . . . gathering information as to the race/ ethnic identification of an individual by direct inquiry is not encouraged."101 Self-reporting, it is emphasized, should only be a last resort when "all other methods prove impractical and burdensone."102 Thus, "visual surveys" are the predominant ineans of employee classifica-

1 either by visual surveys of the work force, or at their option, by the maintenance of post-employment records as to the identity of employees." According to the EEO-4 instructions, although the Commission does not encourage direct inquiry as a method of determining racial or ethnic identity, this method is not prohibited ... where other methods are not practical, provided it is not used for purposes of discrimination.

... [With] employees . . . located at different addresses . . . it is recommended that visual surveys be conducted for the employer by persons such as supervisors who are responsible for the work of the employees or to whom the employees report for instruction or otherwise.

EEOC FORM 164, supra note 77, at 5.

97. EEOC FORM 274, supra note 76 , at 2.

98. Id.

99. Id. Visual surveys are perhaps even more common in the hiring process, where it is in many states illegal to ask about applicants' race in job interviews. It is either discouraged or illegal to ask applicants about their race in 23 states, to ask about the color of their skin, eyes, or hair in 27 states, to ask about their national origin, ancestry, or lineage in 25 states and to require a photograph as part of a job application in 26 states. Memorandum from Jeffrey A. Norris, President, Equal Employment Advisory Council, to EEAC Members app. (Aug. 9, 1990) (regarding state prohibitions on preemployment inquiries). Even where inquiries are permitted (as they are by federal preemption after hire), state officials join their federal counterparts in recommending "visual surveys." The New York Division of Human Rights, for example, wams of "the disquieting effects which such [direct] surveys may engender. It is advisable to gather ethnic data by indirect means rather than by direct and overt inquiry of employees, apprentices, or tenants." NEw YORK: PRE-EMPLOYMENT INQUIRY GuIDE, [8B Fair Empl. Prac. Man.] Lab. Rei.. Rep. (BNA) No. 747, at 456:7501, 456:7506 (May 1994).

100. EEOC FORM 274, supra note 76, at 2.

101. Id.

102. Id. (suggesting certain notice and confidentiality procedures). Firms filling out EEO reports are advised that "[r]ace/ethnic designations as used by the [EEOC] do not denote scientific definitions of anthropological origins. For the purposes of this report, an employee may be included in the group to which he or she appears to belong, identifies with, or is regarded in the community as belonging." Id.; see also STANDARD ForM 100, supra note 72, at 5 (containing identical wording). The "visual survey" is thus the primary means of employee-classification by unions and firms for EEO purposes, and only if there is any "doubt" about employee identity are employers likely to consider asking an employee to self-identify. Telephone Interview with Lynwood Battle, supra note 92. 
tion; the employer-submitted EEO information is grounded in the subjective assessments of individual personnel administrators-who are not, one might suspect, entirely disinterested in the outcome-about whether an employee, for example, "looks Black" or "seems Hispanic."103 This information is judged against self-reported MSA data.

This mechanism, which juxtaposes the apples of self-reported race and ethnicity with the oranges of stereotyped group ascription, is the foundation of federal EEO enforcement. This conceptual mishmash might not be troubling were race a "hard" variable like biological sexual identity because, barring disguise or deception, the two systems might be expected to classify individuals identically. Given the analytical muddiness of "race," however, we cannot be sure that either the procedures employed in census classification or the "visual survey" methods used by employers will closely track the distribution of race-based disadvantage at which the remedial thrust of EEO policy is presumably aimed. An enforcement system based upon the coniparison of data derived from these two types of procedure arguably does a poor job of addressing the reniedy to the wrong.

\section{B. Electoral Redistricting}

Recent controversies before the U.S. Supreme Court illustrate another important use of racial classifications, nanely the allocation of political power along racial lines through the adjustment of voting district boundaries. Such mechanisnis have long been used to disadvantage minorities and ensure White political control of democratic processes. In Gomillion $v$. Lightfoot, ${ }^{104}$ for example, the Supreme Court invalidated an attempt of the Alabama Legislature to change the shape of Tuskegee, Alabania, "from a square to an uncouth twenty-eight-sided figure" in such a way as to disempower minority voters and ensure a continued White monopoly of political power. ${ }^{105}$

Like race-conscious employment and promotion, however, electoral district adjustment has in recent years become an iniportant weapon in the federal government's reniedial anti-discrimination arsenal. Today, the Justice Department oversees state and local voting law and policy to ensure that redistricting does not adversely affect minorities, sometines stepping in to redraw boundaries so as to adjust the likely proportion of minorityelected officeholders. Since the 1990 Census reapportioned congressional seats across the country, state legislatures have, under the Voting Rights Act, created some twenty-six so-called "minority-nıajority" congressional

103. The "visual survey" method does not specify whether it is permissible for an employer to consider the speech patterns or dialect of employecs in making classifications for EEO purposes. In practice, of course, there is no oversight of employer decisions, so they are free to consider whatever factors they feel to be appropriate.

104. 364 U.S. 339 (1960).

105. Id. at 340 . 
districts ${ }^{106}$ and innumerable smaller ones-for everything from state legislative elections to water district boundaries.

The recent furor over North Carolina's proposed congressional District 12 illustrates most dramatically the development of race-conscious electoral allocation. As a result of the 1990 census, North Carolina became eligible for a twelfth seat in the U.S. House of Representatives, and the state General Assembly set about drawing up a redistricting plan. Forced to comply with section 5 of the Voting Rights Act of $1965,{ }^{107}$ which required that any changes in its voting laws or districting be approved by the federal government, ${ }^{108}$ the state submitted the redistricting plan to the U.S. Attorney General for vetting. The General Assembly plan had already created one "minority-majority" congressional district-peculiarly shaped so that Blacks in it were a majority-but the U.S. Attorney General felt that North Carolina should have created a second "minority-majority" district as well.

The state drew up a revised redistricting schene which was approved by federal officials. This revised plan created District 12, which became the focus of controversy because of its peculiar geographical shape. As Justice O'Connor described it:

The second majority-black district, District 12 , is . . . unusually shaped. It is approximately 160 miles long and, for much of its length, no wider than the I- 85 corridor. It wimds in snake-like fashion through tobacco country, financial centers, and manufacturing areas "until it gobbles in enough enclaves of black neighborhoods." Northbound and southbound drivers on I-85 sometimes find themselves in separate districts in one county, only to "trade" districts when they enter the next .... One state legislator has remarked that "[i]f you drove down the interstate with both car doors open, you'd kill most of the people in the district." 109

This effort was intended to ensure that the state's Black citizens, as a group, would have political representation more proportionate to their share of the population. Though the North Carolina population was twenty percent Black, ${ }^{110}$ in more than ninety years the state had never sent a nonWhite representative to Congress. ${ }^{111}$ As a result of the redistricting plan, Eva Clayton and Melvin Watt became the state's first black representatives

106. Gerrymandering; Whither Shall it Wander?, ECONOMIST, July 10, 1993, at 18.

107. 42 U.S.C. $\$ 1973 \mathrm{c}(1988)$.

108. 42 U.S.C. $\$ 1973 \mathrm{c}$ provides that changes in voting law or policy in designated areas be approved by the U.S. District Court for the District of Columbia, or, in advance, by the U.S. Attomey General.

109. Shaw v. Reno, 113 S. Ct. $2816,2820-21$ (1993) (citations omitted) (some internal quotation marks omitted).

110. Id. at 2820.

111. See Brenda Wright, Yes: Toward a Politics of Inclusion, A.B.A. J., July 1993, at 44. 
since $1901,{ }^{112}$ joining a record number of thirty-eight blacks on Capitol Hill. ${ }^{113}$

In June 1993, the Supreme Court reaffirmed that "district lines obviously drawn for the purpose of separating voters by race require careful scrutiny under the Equal Protection Clause regardless of the motivations underlying their adoption," 114 and permitted a challenge to the legality of District 12 to be heard in a North Carolina federal district court. ${ }^{115}$ Regardless of the ultimate fate of District 12, however, this decision certainly will not end the debate over race-conscious reapportionment of electoral districts. In her opinion, Justice O'Connor carefully noted that '[ $[\mathrm{t}] \mathrm{his}$ Court never has held that race-conscious state decisionmaking is impermissible in all circumstances." 116 Rather, the Court limited its application of strict scrutiny under the Equal Protection Clause to "reapportionment plan[s] . . . so highly irregular that . . . [they] rationally cannot be understood as anything other than an effort to 'segregat [e] ... voters' on the basis of race."117 Redistricting plans following more "traditional" districting principles-or perhaps even ones of District 12's irregularity, if narrowly tailored and armed with a "sufficiently compelling justification" 18 -would presumably still pass muster. Most "minority-majority" districts around the country, therefore, do not appear to be in immediate danger, nor does the Court's holding on its face implicate the legitimacy of anti-discrimination "results" testing under section 2 of the Voting Rights Act.

It is clear in this area that a coherent accounting of "who is what" is still necessary. Whether used to invalidate or enjoin state or local districting or voting rules under section 2 of the Voting Rights Act, or, more dramatically, to encourage "minority-majority" electoral districts pursuant to section 5, voting rights law depends fundamentally upon the veracity and coherence of its statistical database and the intelligibility of whatever theory of racial identity underlies it. The local and regional group population statistics that are the backbone of U.S. voting rights enforcement come from the U.S. census - which the Bureau makes available, for a fee, in easily accessible computer database form to state and local governments around the country, as well as to private individuals. These are the same basic figures used by EEOC and OFCCP officials in evaluating private employment practices.

112. Id.

113. House of Representatives; Old Jowls, New Faces, ECONOMIST, Nov. 7, 1992, at 29 (noting a jump from 25 to 38 Black representatives).

114. Shaw, 113 S. Ct. at 2826.

115. Id.

116. Id. at 2824 .

117. Id. at 2826 (quoting Gomillion v. Lightfoot, 364 U.S. 339, 341 (1960)) (third modification and third omission in original).

118. Id. at 2824 . 
Thus voting rights law is built upon a self-identified population pool that records ethnic and national-origin data entirely independently of race. It is administered, however, as if race and ethnicity were mutually-exclusive categories, and nearly four percent of all responses are statistically "modified."119 Since voting rights applications deal with much larger statistical samples than employment discrimination law-with entire political districts, for example, rather than with the shop floor of a single employer-the distortions and ambiguities of a self-reported database are likely to be less damaging in this context. Electoral redistricting does not advantage or disadvantage individuals in the immediate sense that preferential policies in the workplace do; it is not a system for allocating particularized benefits. Nevertheless, as Cabranes' Puerto Rican example illustrates, ${ }^{120}$ even at this more abstract level it may be unwise to take such figures entirely for granted. Procedures of census response-"modification" have an impact upon classifications in a particular locality, and could thereby have an undue influence upon race-based electoral redistricting. In four U.S. counties, it should be recalled, the Census Bureau overrode "race modification" results when they resulted in "too many" individuals being classified as Native Americans. ${ }^{121}$ If redistricting is to maintain its enormous importance in the allocation of political representation, and if such programs are indeed to remedy discriminatory wrong, the electoral engineers and the population surveyed by the census must both be speaking the same classificatory language.

\section{Alternative Approaches to Identity}

In attempting to remedy race-related wrongs, our social engineers work with data which is as conceptually inuddy and contextually contingent as our notions of race and ethnicity theinselves. Accordingly, it is unwise for courts and administrators simply to assume that the foundations upon which they erect these platforms of public policy and jurisprudence are solid. Rather these foundations should be examined with care. The weakness such examinations uncover deserves close attention. The Malone case suggests that race-administrative systeins grounded in personal self-identification may not survive sustained pressure, especially in areas with immediate and concrete personal impact, such as employment preferences. To help us understand inore about other classification systems, the next sections will examine some alternative approaches to racial identity used in the United States.

119. See supra notes 57-63 and accompanying text.

120. See supra notes $67-70$ and accompanying text.

121. See supra note 65 and accompanying text. 


\section{Crime Statistics}

The Federal Bureau of Investigation (FBI) has chosen its own method of racial and ethnic classification in its breakdown of national crime statistics. Crime statistics are compiled from monthly reports filed voluntarily by city, state, and local law enforcement agencies from across the country. To facilitate these compilations, the FBI requests that data be tabulated according to "Uniform Crime Reporting" (UCR) criteria which ensures uniformity in the quantity and quality of data provided with each submission. UCR guidelines include requests for the age, sex, race, and ethnic origin of all offenders arrested by local police forces. ${ }^{122}$ At present, comprehensive accounting of the race and ethnic origin of victims is usually available only for the crime of murder, a crime for which the FBI information requests are unusually stringent. ${ }^{123}$ To standardize the format of submissions, the FBI requires local law enforcement authorities to choose from among only five standardized codes for race and three for ethnicity (Hispanic, non-Hispanic, and unknown). ${ }^{124}$

Unlike the census classifications, crime statistics are not self-reported. Because it is often difficult to obtain racial and ethnic self-identifications from either arrestees or victims, officers filling out arrest logs and afteraction reports commonly use no more than the informal "visual survey" method. ${ }^{125}$ The FBI offers only vague definitions associating different racial groups with the "original peoples" of various areas of the world (Europe, Africa, East Asia, and so forth), and "Hispanic" persons as those of any "Spanish culture or origin, regardless of race."126 Officers therefore have little choice but to fall back upon cultural stereotypes when classifying victims and offenders. A man who "looks Black" or "seems Hispanic," for example, will be so recorded based upon the arresting officer's intuitive assessment of his racial and ethnic identity.

Thus, the method of racial classification used in the compilation of crime statistics is no more sophisticated than the EEOC's stereotype-driven employer-reported "visual survey" methods. It lacks even the minimal theoretical oversight of employee identification provided in the EEOC context by EOS officer on-site inspections. In crime reporting, the "visual survey" discretion of reporting officers is left entirely unquestioned.

122. FBI, U.S. Dép't of Justice, Uniform Crime Reporting Handbook 58, 84 (1984) [hereinafter FBI HANDBOOK].

123. Id. at 63!65. A computerized national law enforcement data system, the National IncidentBased Reporting System (NIBRS), in which comprehensive incident-by-incident reports will be collected for every major crime, may be on the horizon, however. Telephone Interview with Joe Sabbataso, New Haven Police Department (Mar. 10, 1993); Telephone Interview with Official at FBI Uniform Crime Reporting Unit, Washington, D.C. (Mar. 10, 1993).

124. FBI HANDBOoK, supra note 122, at 63-64. Most police forces do not presently collect ethnicity information, but with the NIBRS system this data will be reportable on an optional basis. Telephone Interview with Gary Lopez, Connecticut State Police (Mar. 11, 1993).

125. Telephone Interview with Gary Lopez, supra note 124.

126. FBI HANDBOOK, supra note 122 , at 58. 


\section{Vital Statistics}

Whether self-reported or subjectively ascribed, the racial and ethnic classifications of the FBI's UCR division do not have much direct effect upon the individuals classified thereunder. Race classifications for vital statistics such as birth and death certificates, on the other hand, have a potentially much greater individual impact. As we have seen in Malone v. Haley, the administrative resolution of disputes over alleged mistakes in racial classification for purposes of hiring and promotion may hinge upon the racial status designated on a birth certificate. ${ }^{127}$ Because birth certificate data includes race, it may often be-as Malone illustrates-a tempting source of official "documentary evidence" for "double-checking" or "second-guessing" other methods of individual classification. This potential "official" status of vital statistics data, however, is especially worrisome because the origin of this data is even quirkier and more questionable than the data generated by the census or EEO systems.

The procedures generally used in making birth certificate race-identification records are outlined in guidelmes prepared for state and local governments by the National Center for Health Statistics (NCHS) in Washington. ${ }^{128}$ From 1950 to 1989 , these federal guidelines included a procedure for determining the race of a child from the self-reported race of its parents. The mother and father were asked their respective races, to be coded as follows: White (comprising Mexican, Puerto Rican, and other Caucasian) 1; Black 2; Indian (North, Central, and South American Indian, and Eskimo and Aleut) 3; Chinese 4; Japanese 5; Hawaiian (including partHawaiian) 6; Filipino 7; Other Asian or Pacific Islander 8; Other races 0; Not classifiable $9 .{ }^{129}$ The race of the child was then determined according to a formula supplied by the NCHS:

[1]n cases of mixed parentage where only one parent was white, the child was assigned to the other parent's race. When neither parent was white, the child was assigned the race of the father, except if either parent was Hawaiian, the child was assigned to Hawaiian. If race was not reported for one parent, the child was assigned the race of the parent for whom race was given. ${ }^{130}$

Nonresponses were coded "not-classifiable." Additionally, if the race of the mother was coded not classifiable, the mother's race was recorded as

127. Recall that in Malone, the Malone brothers failed the "documentary evidence" prong of the race-verification test adopted by the court because their birth certificates and those of their parents indicated "White" status. Malone v. Haley, No. 88-339, slip op. at 18 (Sup. Jud. Ct. Suffolk County, Mass. July 25, 1989).

128. See National Ctr. for Health Statistics, U.S. Dep't of Health \& Human Servs., Instruction Manual, Part 12: Computer Edtrs for NataltT Data, Effective 1989, at 14 (1989) [hereinafter Instruction MANUAL, PART 12].

129. Id.

130. National Ctr. for Health Statistics, U.S. Dep't of Health \& Human Servs., Advance Report of Final Mortality Statistics, 1989, Montrly Vrtal Stat. Rep., Jan. 7, 1992, at 50. 
that of the father, if known. If neither parent's race was known, officials were to "impute mother's race as race of mother of the preceding record with known race of mother."131 State health officials generally followed this system with only minor modifications. ${ }^{132}$

This coding algorithm embodied a number of curious assumptions. One notable characteristic is that any coupling between Whites and nonWhites was deemed to produce non-White children. White racial status could only be removed by inter-group parentage, never gained. ${ }^{133}$ The origins of this categorization are obscure, but it may reflect shopworn racist assumptions about race "pollution"- that White status may only be "lost" by admixture, forfeited by foreign "taint." By the formal logic of the system, no amount of breeding with Whites will confer "White" status to a "non-White." Standing in stark contrast to this attribute of "White" status, Hawaiian status was defined so as to include any conceivable degree of "part-Hawaiian" descent, so that a code 6 (Hawaiian) parent always produced code 6 (Hawaiian) offspring no matter what the race of the other parent. ${ }^{134}$ Thus, in a sense, the status of "Hawaiian" was the morphological polar opposite of that of "White." While "White" status could only be maintained through the most selective breeding with other Whites, it was defimitionally impossible to shake a "Hawaiian" designation: a child with one Hawaiian parent by this system was always "Hawaiian"; so also was that child's child, and so on indefimitely. Something in Hawaiian "blood" was apparently so indelible that it could never be erased.

In practice, since this system was self-reported and no attempt was made to ensure that one's self-identification corresponded to prior birth certificates, each generation was effectively classified anew. This system, in other words, was effectively "re-started" with each generation. Nevertheless, this does not mean that classifications on prior birth certificates are meaningless. We should not forget that Judge Wilkins employed a sort of birth certificate-derived racial estoppel against Paul and Philip Malone by judging their racial status in part according to the designations of their parents

131. Instruction Manual, Part 12, supra note 128, at 14.

132. For example, Connecticut's Department of Health Services stipulated that when the race of both parents was unknown, and either parent was deemed to have been of Hispanic origin, the child would be classified as "White." See Letter from Karen Frost, Research Analyst, Office of Health Policy Development, Health Surveillance and Planning, Connecticut Department of Health Services, to Christopher Ford, attachment (Mar. 12, 1993) (on file with author).

133. See id. The NCHS coding system, however, rested upon a voluntary self-identification by the parents; the system made no effort to hold parents to the race classifications they themselves had been assigned at birth.

134. See William Petersen, The Classification of Subnations in Hawaii: An Essay on the Sociology of Knowledge, 34 AM. Soc. Rev. 863 (1969); William Petersen, Chinese Americans and Japanese Americans, in Essays and Data on American Ethinic Groups 65, 73 (Thomas Sowell ed., 1978). 
and grandparents. However odd this system of classification may be, it is sometimes accorded probative value in individual cases. ${ }^{135}$

This coding system was abandoned by NCHS in 1989 in part because it was felt that "the increasing incidence of interracial parentage" combined with "the growing proportion of births with race of father not stated" made it "more appropriate to tabulate births by the mother's race" than to use a "necessarily arbitrary combimation of parental races." 136 Since 1989, NCHS has required the following system:

Birth data are tabulated by the race of the mother as reported directly on the birth certificate. If race of mother was not stated, it was imputed as that of the father, if known. If neither race was stated, race of mother was imputed as the race of the mother on the preceding record with known race. ${ }^{137}$

The 1989 birth certificate revisions have also attempted to obtain more specific information on race. The new 1992 guidelines, for example, require several states to adopt an elaborate series of subcategories for Asian or Pacific Islander respondents. ${ }^{138}$ Additionally, the 1989 revision of standardized birth data guidelines also contained a question about the mother's Hispanic origin on birth certificates. ${ }^{139}$

Despite these attempts to improve the system, the post- 1989 system is in some ways as odd as its predecessor. The race of one's father is irrelevant unless the mother's race is simply unknown or not otherwise available. Racial status in this formal system is thus rigidly matrilineal. Within this system, race can never change or be escaped except by accident of sexchromosomal inheritance: only through male children can race be "changed." A Black woman's female progeny would remain Black for indefinite generations even should they marry Whites or even Hawaiians. The new coding system, like the old, effectively "re-starts" with each matrimonial self-identification. Women are not required to self-identify according to their own birth classification, but the potential for certificate-based

135. At the level of aggregate population statistics, moreover, the structure of the coding system might have produced results at variance with conventional ideas of racial identity. Assuming, under prevailing social conventions, that at some ancestral "distance" non-White parentage will become "invisible," the classificatory logic of the old NCHS system would have overestimated the non-White population by designating any and all descendants of non-Whites as non-Whites. However, asking parents to self-identify may have mitigated much of this distortion at the aggregate level.

136. National Ctr. for Health Statistics, U.S. Dep't of Health \& Human Servs., Advance Report of Final Natality Statistics, 1990, MoNTHLY VITAL STAT. REP., Feb. 25, 1993, at 49 thereinafter Natality Statistics, 1990].

137. National Ctr. for Health Statistics, U.S. Dep't of Health \& Human Servs., Advance Report of New Data from the 1989 Birth Certificate, Monthly Vrtal Stat. Rep., Apr. 15. 1992, at 29.

138. National Ctr. for Health Statistics, U.S. Dep't of Health \& Human Servs., Instruction Manual, Part 3A: Classtfication and Coding instructions for live Birth Records, 1992, at 16 (1992) [hereinafter Instruction Manual, Part 3A].

139. Instruction MANuAL, PART 3A, at 15. By the 1990 data year, a mother's Hispanic or nonHispanic origin was required information on $99 \%$ of birth records nationwide. See Natality Statistics, 1990 , supra note 136 , at 11 . 
estoppel as applied in Malone remains. As a conceptual system, the new method is dauntingly peculiar, and at best has only an arguable connection to the sociological reality of race and discrimination. Irrespective of his self-perception, or society's perception of him, for example, the child of a Black man and a White woman would forever possess a birth certificate classifying him as White.

Since both NCHS reporting systems have relied heavily upon racial and ethnic self-identification by infants' parents, elaborate methods have been devised for dealing with nonresponses and with nonstandard write-in answers for "other" categories. Maternal nonresponses where the father's race is unknown, as we have seen, are assigned "the race of the mother on the preceding record with known race."140 Thus if a mother neglects to fill in the proper check-box on her hospital birth certificate "worksheet" while recuperating from childbirth, her child will be assigned a race according to the race indicated on the previous record encountered by the data-entry clerk. Where no race or Hispanic origin is recorded (because the mother could or would not self-report), "unknowns" are distributed randomly. ${ }^{141}$

The NCHS office in Washington, D.C. promulgates guidelines governing how local health officials are to fold write-in "other" responses back into the standardized codes. ${ }^{142}$ Although generally no second-guessing of written "other" entries takes place, coding "Indian" with a recorded birthplace outside the Americas is re-classified as "Other API" (or "Asian Indian" where available). ${ }^{143}$ To help state officials compile standardcategory data from the diverse responses received in "other" write-ins, the NCHS provides lists of common self-designations with instructions as to how each may be coded back into the standard categories. Thus, for example, racial identity responses of "Amerasian," "Indo-Aryan," "Ubontilian," or "Hindu" are to be coded as "Other API," while "Anglo-Saxon," "Afghanistan," "Hebrew," "Hispami," "Mohammedan," and "Zoroastrian" are all considered "White." 144 As can be seen, certain religious affiliations under this system are allotted racial characteristics: Hindus are presump-

140. See supra note 137 and accompanying text.

141. Telephone Interview with Lloyd Mueller, Connecticut Department of Health Services (Mar. 8, 1993).

142. Racial entries written as "Asian," "Yellow," "Oriental," or "Mongolian," for example, are to be entered as code 8 ("Other API"). The entries of "Afro-American," "Colored," "Negro," or "Brown" are to be folded back in as code 2 (Black). If Hawaiian identity is reported along with any other response (e.g. "Chinese-Hawaiian"), the entry is coded simply as "Hawaiian." With fractional responses, such as half-Japanese, the prefix is disregarded and the race is coded as reported. Instruction Manual, Part 3A, supra note 138, at 16-17.

143. Id. at 17 .

144. This coding hist is taken from the version of the NCHS list used by the Connecticut Department of Health Services-the Automated Vital Statistics Systems (AVSS). See Letter from Karen Frost, supra note 132, attachment, AVSS Races Sorted by NCHS Code thereinafter AVSS Races Sorted by NCHS Code]. The master NCHS list is found in Instruction MANUAL, Part 3A, supra note 138, app. E. 
tively Asian, Jews and Muslims presumptively White. ${ }^{145}$ Mysteriously, responses of "Nassau" (the capital of the Bahamas) result in an NCHS coding as "Black," while answers of "Bahamian" are coded merely as "Not Classifiable or Unknown."146 A similar list aids state officials in coding nonstandard responses to the Hispanic-origin question back into the primary categories: "Falkland Islands" or "Guatemalteco" is to be coded 4 (Central or South American), "Basque," "Valencian," or "La Raza" responses become code 5 answers ("Other Hispanic"), while "Amish," "Bahamian," "Jewish," or "White" are classified as 9 (non-Hispamic) ${ }^{147}$ Incongruously, for the Hispanic-origin question a written response of "White" is treated as "non-Hispanic," while for the racial-origin question a response of "Hispanic" is treated as "White." 148

This algorithmic folding of nonresponses or idiosyncratic responses like "Ubontilian" back into the standardized category codes does not occur inerely at the aggregate level, when NCHS compiles its annual natality statistics. Astonishingly, this process also takes place for individual birth certificates. As part of their "quality assurance follow-up," Connecticut health officials, for example, endeavor to ensure that every individual birth certificate is given both a race and an ethnicity code. Where no responses are recorded or a 9 ("Not Classifiable") entry is given, this might consist of contacting local physicians and having them try to re-establish contact with inothers for the purpose of soliciting a self-categorization more intelligible to the bureaucrats. Nonstandard written responses, if they appear on the master NCHS lists of "alternative" group names, are accordingly re-coded as standardized categories. When these inethods fail, the certificates might be left as "unknown"- a category of little use for estoppel or other later adjudicative purposes. ${ }^{149}$

This is the sort of system upon whicl judges will have to rely for "documentary evidence" of the race of future "Malones." Ultimately, as with the self-reported information on U.S. Census forms, the system lacks any "reality" check: what if Mrs. Malone had grinned and said "Black"

145. See AVSS Races Sorted by NCHS Code, supra note 144. The NCHS system appears to work around the principle of statistical likelihood, but it should be clear from this coding system that on a certificate-by-certificate basis its results may not always conform to our preconcieved notions of racial commumity. Self-identification by religious affiliation, for example, might result in the children of Louis Farrakhan being given birth certificates identifying them as White.

146. Id.

147. See Letter from Karen Frost, supra note 132, attachment, AVSS Ethnicity List [hereinafter AVSS Ethnicity List]. The master NCHS list is found in Instruction MANual, Part 3A, supra note 138, app. H. Written responses may also be checkèd against the NCHS list of recognized Indian tribes from the United States, Canada and Mexico. See id. app. F.

148. Compare AVSS Races Sorted by NCHS Code, supra note 144 with AVSS Ethnicity List, supra note 147.

149. Altematively, if "unknowns" were coded as the NCHS recommends for statistical accounting - that is, by "imputing" identity based upon the race of the mother with the "previous record with known race," see supra note 137-the result would be downright perverse: essentially a random assignment of race. 
when so asked by the hospital orderly? Had the twins' parents had more of a sense of humor-or more foresight?-their boys' career in the Boston Fire Department might have had a different ending.

\section{III}

\section{A Comparative Analysis}

Can comparative law in any way illuminate our classificatory dilemmas? One potential avenue of enlightenment is to look at how the American legal system deals with classification for other group categories. Another avenue is to look at how other legal systems approach the subject of group definition and status-allocation. The next several sections will briefly discuss examples drawn from U.S. and foreign experience with these dilemmas.

\section{A. The Easy Cases}

In many cases, the definition of groups and the drawing of lines between individuals has not proven problematic at all. To the extent that a particular group can be defined according to clear and invariant characteristics or criteria, the administration of programs allocating benefits according to membership or nonmembership is not particularly taxing. Alternatively, even a highly socially-contextual "fuzzy" group definition can be workable if we, for example, (1) accept a principle of "fractional descent" by which the genealogical "closeness" of a group-member ancestor can be calculated by reference to a primordial "base population," or (2) allocate the establishment of membership criteria either to the members of some base population or to an official decision-inaking third party.

\section{Sex Classification}

As we have seen, the drawing of lines between men and women is comparatively unproblematic. At the most basic level, it is technically possible to refer to an empirical scientific standard. For example, women competing in the Olympics might be given "Barr body" tests for the presence of a second, vestigial $\mathrm{X}$ chromosome in order to ensure that they are indeed female. The definition of sexual type is at this level straightforward. Moreover, in the day-to-day world, without sophisticated medical paraphernalia, distinguishing between men and women is relatively uncomplicated. At the point of imtimacy, genitalia usually inake the matter unmistakable, ${ }^{150}$ but even im a more social setting the presence or absence of particular secondary sexual characteristics provides a generally reliable test. The more or less dichotomous nature of the sex variable ensures that any group-preferential program based upon sexual classification would be-in its definitional terms, at least-relatively uncontroversial.

150. See, e.g., The CRYng GAME (Miramax 1992). 


\section{Native Americans}

A more complex example is that of the definition of Native Americans for purposes of U.S. law and tribal court jurisdiction. In a scientific sense, there is no apparent basis for differentiation on "Indian" status grounds. There are no unmistakable and invariant physical characteristics and there is no genetic litmus test. As with race and ethnicity, the category is primarily a socially-constructed one. Nevertheless, it poses fewer administrative problems than race or ethnicity, because the administrative system defers, in making classificatory choices, to a "pohtical" process of "memberreference," making no claims to objective integrity.

Most "Indian law" in the United States focuses upon tribes rather than upon individuals, but there are enough exceptions to muddy the waters. ${ }^{151}$ Traditionally, the term "Indian" was conceived in classically racial terms. In 1846, for example, the Supreme Court ruled that a White person adopted by an Indian tribe was not Indian for federal jurisdictional purposes. ${ }^{152}$ Indians under United States law have seldom been regarded as an undifferentiated group, however, and jurisdictional statutes governing tribal courts and other measures have usually held "Indian" status to obtain primarily through specific tribal affiliation. The Indian Reorgamization Act of 1934, for example, defined "Indian" to include

all persons of Indian descent who are members of any recognized Indian tribe now under Federal jurisdiction, and all persons who are descendants of such members who were, on June 1, 1934, residing within the present boundaries of any Indian reservation, and shall further include all other persons of one-half or more Indian blood..$^{153}$

This classification system made Indian categorization largely a function of recognition by the tribe itself, combined with the delineation of a specific population base group of tribal affiliates and direct descendants. ${ }^{154}$ This essentially tribe-by-tribe approach has been an enduring tradition of U.S. "Indian" law. Even where statutes defined the scope of governinent

151. The Indian Civil Rights Act requires tribes to honor certain provisions of the Bill of Rights and other individual protections from which they would otherwise be exempt. 25 U.S.C. $\$ 1302$ (1988 \& Supp. V 1993). Some statutes, cases, and regulations define "Indian" differently for different purposes. For example, the Indian Health Care Improvement Act provides separate definitions for "Indian," "Urban Indian," and "Rural Indian." 25 U.S.C. \$ 1603 (1988 \& Supp. V 1993). Urban Indians, Indians who live outside traditional tribal enclaves, are included for purposes of alcohol treatment programs and recruitment into the health professions, but are excluded from other plans. Id. Historically, the use of differing criteria to determine Indian status has caused the listed U.S. Indian population to vary significantly. Census figures show a 14 percent increase in the Indian population between 1960 and 1970, but a doubling of that population between 1970 and 1980. See WEBSTER, supra note 45 , at 144 .

152. United States v. Rogers, 45 U.S. (4 How.) 567, $572-73$ (1846).

153. 25 U.S.C. $\$ 479$ (1988).

154. It was not, however, entirely clear wbat the "persons of one-half or more Indian blood" clause meant, as the deseent system was complicated by the admixture of both tribe-"membership" criteria and some undefined notion of "blood." 
aid programs as applying to "Indians throughout the United States,"155 administrative policy has often attempted to limit programs to Indians living on reservations or having particularly close tribal ties. ${ }^{156}$

In the area of tribal court jurisdiction, the Supreme Court in Oliphant v. Suquamish Indian Tribe ${ }^{157}$ ruled that tribal courts had no jurisdiction over non-Indians. Shortly thereafter, in United States $v$. Wheeler, ${ }^{158}$ the Court interpreted Oliphant as holding that the jurisdiction of each tribal court system was limited specifically to tribe ineınbers. ${ }^{159}$ Perhaps to avoid the strict scrutiny standard applied to "racial" classifications, ${ }^{160}$ federal case law on tribal court jurisdiction has einphasized that-EEO and MSA classifications notwithstanding - "Indian" is not a "race" category, but is rather a designation "based on a totality of circumstances, including genealogy, group identification, and lifestyle, in which no one factor is dispositive."161

Though not wholly consistent with traditional U.S. practice, ${ }^{162}$ perhaps the inost ingenious approach to classification was taken by the Supreme Court in Morton v. Mancari. ${ }^{163}$ In that case, non-Indian eniployees of the Bureau of Indian Affairs (BIA) brought suit to challenge a BIA preference program for Indians. Justice Blackmun, writing for the Court, held that this pro-Indian BIA preference was not actionable invidious discrimination. Blackmun reasoned that, under the legislative scheine of the Indian Reorgamization Act of 1934, Congress had the permissible goal of ending the situation "whereby the primarily non-Indian-staffed BIA had plenary control, for all practical purposes, over the lives and destinies of the federally recognized Indian tribes." 164

155. See, e.g., Snyder Act of 1921, 25 U.S.C. $§ 13$ (1988) (authorizing social services programs).

156. See, e.g., Morton v. Ruiz, 415 U.S. 199, 212-30 (1974). The Secretary argued that the Bureau of Indian Affairs' (BIA) budget requests consistently contained "on reservations" language, and that assistance "was customarily so restricted." Id. at 212 . Nevertheless, the Court held (1) that Congress was led to believe that programs were being implemented for Indians both on and near the reservations, id. at 213-19, and (2) that near-reservation Indians had been been improperly excluded from receiving benefits because the BIA had not complied with the requirements of the Administrative Procedure Act, id. at 232-36.

157. 435 U.S. 191 (1978).

158. 435 U.S. 313 (1978).

159. Id. at 326.

160. See Peter Tasso, Note, Greywater v. Joshua and Tribal Jurisdiction Over Nonmember Indians, 75 lowa L. REv. 685, 709-10 \& n.290 (1990).

161. Duro v. Reina, 821 F.2d 1358, 1363 (9th Cir. 1987) (quoting Robert N. Clinton, Criminal Jurisdiction over Indian Lands: A Joumey Through a Jurisdictional Maze, 18 ARIz. L. REv. 503, 518 (1976)). By this standard, for example, the Ninth Cireuit permitted tribal court jurisdiction over certain non-tribe-member Indians with close tribal affiliations. The Eighth Circuit, however, flatly refused tribal court jurisdiction over nonmembers, which is arguably more consistent with Wheeler. Greywatcr v. Joshua, 846 F.2d 486 (8th Cir. 1988).

162. Peter Tasso, for example, notes that jurisdiction over Indians was sometimes historically permitted even where they were not members of recognized tribes. Tasso, supra note 160 , at $695-700$.

163. 417 U.S. 535 (1974).

164. Id. at 542 . 
Significantly, the Morton Court expressly declared the designation "Indian" to be a predominantly political one:

The preference is not directed towards a "racial" group consisting of "Indians"; instead, it applies only to members of "federally recognized" tribes. This operates to exclude many individuals who are racially to be classified as "Indians." In this sense, the preference is political rather than racial in nature. ${ }^{165}$

The BIA Indian preference, therefore, was in keeping with the expressed legislative intent of Congress "to promote economic and political self-determination for the Indian." 166 Because the preference was "reasonable and rationally designed to further Indian self-government," the program did not constitute a violation of plaintiffs' due process rights. ${ }^{167}$

The Morton concept has, at least, the virtue of formal consistency. Indian tribes occupy a peculiar niche within the United States constitutional system as "domestic dependent nations," 168 retaining some of a prior independent sovereignty enjoyed before the coming of Whites to the Americas and preserved by treaty negotiations with the U.S. government. ${ }^{169}$ The "doniestic" part of the "domestic dependent nations" formulation ensures that Indian tribes are no longer sovereign enough to make alliances with or alienate land to foreign nations. ${ }^{170}$ Being deemed sovereign powers which have negotiated their attachment to the United States, however, Indian tribes may define the limits of their jurisdiction and the contents of their membership rolls vis-á-vis the federal system with a great deal of freedom-as, by analogy, delineations of citizenship by foreign states are given deference by U.S. authorities. The status of Indian tribes as quasiindependent entities more sovereign (in some sense) than the constituent states of the Union themselves, has allowed Indian case law to escape both constitutional "strict scrutiny" and many of the conceptual ambiguities we

165. Id. at 553 n.24.

166. Id. at 543 n. 15 .

167. Id. at 555 .

168. Cherokee Nation v. Georgia, 30 U.S. (5 Pet.) 1, 17 (1831).

169. In contrast to the semi-sovereign status of Indian tribes in the United States, "Indians" under Canadian law have always been regarded simply as subjects of the Crown. Treaties reached with White settlers are deemed mere contracts, creating some obligations and rights but implicating no real "sovereignty":

It is obvious that the Lake-Huron Treaty, like all Indian treaties, was not a treaty in the international law sense. The Ojibways did not then constitute an "independent power," they were subjects of the Queen. ... The agreement can therefore be said to be tantamount to a contract, and it may be admitted that a breach of the promises contained therenu may give rise to an action in the nature of an action for breach of contract.

Pawis v. The Queen, 102 D.L.R.3d 602, 607 (Fed. Ct. 1979). The Canadian government was given plenary authority in 1867 to legislate in relation to "Indians, and Lands reserved for Indians" in the Constitution Act of 1867. Constitution Act, R.S.C. ch. 5, §91(24) (1867) (Can.). For a discussion of the impact of this Act, and the current state of the law, see generally Noel Lyon, Constitutional Issues in Native Law, in Aborignnal Peoples and the Law: Indian, Metis and Inutr Rights an Canada 408, 418-24 (Bradford W. Morse, ed., rev. 1st ed. 1989) [hereinafter ABorignal. Peoples and tHe Law].

170. Cherokee Nation, 30 U.S. (5 Pet.) at 17-18. 
have seen in the EEO context. The largely tribe-run classification system is a variant of "other-ascription" in which the dispositive factor is perception of group membership by the already-defined inembers of that group. Designating the process a "political" one with its roots in tribal sovereignty avoids the difficulties of membership definition that often bedevil such meinber-referential systems. The prior-sovereignty doctrine clothes the initial designation of group members with the legitimacy of antiquity, enabling the system to proceed with relative ease thereafter.

The designation of "Indian" is, to be sure, not quite as conceptually crisp as the crucial Morton footnote ${ }^{171}$ would suggest. The actual eligibility criteria for the BIA program, for example, stipulated that " $[t]$ o be eligible for preference in appointment, promotion, and training, an individual must be one-fourth or more degree Indian blood and be a member of a federallyrecognized tribe."172 In practice, the process of adjudicating "blood" content inay soinetimes turn out to be a "political" one undertaken by the "recognized" tribes themselves, but it is perhaps significant that the Court was still unable to steer Native American classification entirely away from the dangerous shoals of pseudo-biological "race."

Nevertheless, the prior-sovereignty doctrine distinguishes the group classifications of federal "Indian" law from the unore conceptually difficult contexts of racial and ethnic identity among the general population. Race and ethnicity, unlike the sovereign citizenship to which Indian status is now loosely analogized, cannot so easily be grounded in legally-defined corporate identities. The "political" approach of U.S. "Indian" law is a creature of the peculiar history of Native Americans as peoples with a recognized sovereignty antecedent to their incorporation in the U.S. legal system, and who can thus be said to have some legitimate right to participate in defining their own membership. ${ }^{173}$ Such a definitional system cannot work in the

171. The classificatory innovation of Morton was literally no more than a footnote to the opinion. See 417 U.S. at 553 n. 24.

172. Id.

173. In contrast, the system of defining Indians under Canadian law has traditionally been a matter largely of legislative fiat. Section 2 of the Indian Act, for example, defines "Indian" merely to be "a person who pursuant to this Act is registered as an Indian or is entitled to be registered as an Indian." See Lyon, supra note 169, at 429 . If the government says one is an Indian, so one is. The first government efforts, under legislation pronulgated in 1850 , to compile tribal rolls for this purpose consisted simply of sending "Indian agents" around the country to make lists of those persons they encountered who "were" Indians. Bradford W. Morse, Aboriginal Peoples and the Law, in Aboriornal Peoples and tHe Law, supra note 169, at 1, 1. The people thereby "registered" obtained official recognition as "status Indians" and became wards of the federal government. Federal law sought to "protect" their traditional lifestyle, which meant that they could not imitially vote in federal elections, send their children to public schools, jom the bar, or obtain provincially-administered welfare benefits. Id. As a result of these restrictions, many Indians chose to enfranchise themselves, though doing so forfeited their "registered" status-depriving them of, among other things, the right to live on the reserves, participate in tribal hunting and fishing privileges, and obtain some exemptions from federal taxation. Id. at 1-3.

It was not until relatively recently that some measure of federal recognition for "lost-status Indians" was returned. The Canadian Constitution defined the aboriginal peoples of Canada to include "the 
contexts of race and ethnicity without presuming the very thing formal classification seeks to accomplish: the division of the population into discrete groups of clearly-differentiated individuals. Where there is no identifiable "base population" with a formal structure permitting collective in-group decision-making, the Native American approach to classification by member-reference will be of no use. ${ }^{174}$

\section{B. Other Race-Based Classification Schemes}

Unable to gain much insight from avenues workable in the contexts of Native American and gender classification, it is useful to attempt a comparative survey of the definition and classification methods of legal systems in other countries and other time periods. The problem of categorization arises wherever the allocation of rights, benefits, or disadvantages is in any way tied to group inembership. India, the United States in the "Jim Crow" era, and South Africa during apartheid all developed administrative and judicial schemes to classify those whose status was potentially contestable. Both paradigms of classification-self-reported and other-ascribed-are represented.

\section{India: "Scheduled" Castes and Tribes}

As a way to conbat the pernicious socio-economic effects of the highly rigidified system of caste-based discrimination in traditional Indian society, the federal and state governments of India have developed an elaborate system of reniedial group preferences for members of the "Scheduled Classes" (the so-called "untouchables"), "Scheduled Tribes" (reniote noncaste tribal communities which have suffered front their isolation), and-to a lesser extent-“"Other Backward Classes" (groups higher on the caste lad-

Indian, Inuit and Metis peoples of Canada." CAN. CoNst. (Constitution Act, 1982) pt. II (Rights of the Aboriginal Peoples of Canada), $\$ 35(2)$. Traditionally, the term "Metis" referred to persons of mixed French and Indian ancestry, whereas "Halfbreed" was used to describe English-Indian mixing. Morse, supra at 4. The term today, however, is used to include the descendants of enfranchised ("lost-status") Indians, the descendants of those who were never registered as "status Indians" in the first place, and the descendants of those Indians who traded their "status" standing for money scrip rather than treaty payınents and reservations. Id. The terms "non-status Indians" and "non-registered Indians" are supereeding "Metis." Id.

Recent years may be characterized by more of a negotiation process between the government and Canadian aboriginal peoples. See, e.g., Harvey Feit, The Income Security Program for Cree Hunters in Quebec, Canada: An Experiment in Increasing Autonomy of Hunters in a Developed Nation State, in Aborigines, Land and Land Rights 439, $445-48$ (Nicolas Peterson \& Marcia Langton eds., 1983) (discussing the negotiations between the Indians and the government in 1974-1975). The status of the "Indian" in Canadian law, however, remains primarily one legitimated by the temporal distance of the original "registration" procedures of bureaucratic fiat.

174. Even a system of simple fractional descent, from which subsequent membership might be calculated by some "percentage" of ancestry, see, e.g., Indian Reorganization Act of 1934, 25 U.S.C. $\S \S 2421-2424$ (1988) ("The term 'Indian' . . . shall . . . include all other persons of one-half or more Indian blood."), presupposes a discrete base population of "fullbloods" which does not exist in the context of racial and ethnic identity. 
der than the untouchables but who are nevertheless deemed deserving of some aid). According to the 1971 census, there were approximately eighty million people in the Scheduled Castes (SCs), or about $14.6 \%$ of the country's population, and some thirty-eight million Scheduled Tribes (STs), or 6.9\%. The Other Backward Classes (OBCs), the defimition of which varied from state to state, numbered about sixty million, or $11.8 \%$. $^{175}$

The preferential programs admimistered for these groups are grounded in an understanding that the formal equality guaranteed by the Indian Constitution, alone, would, in a society so deeply riven by caste discrimination and socio-economic divisions, be unequal to the task of providing all Indians with equal status and opportunity. ${ }^{176}$. The Supreme Court of India has held that equal treatment, by itself, would perpetuate "glaring inequalities," and has concluded that some form of preference for the least advantaged was needed "in order to give a real opportunity to them to compete with the better placed people."177

Such constitutional interpretations have permitted a wide range of preferential programs designed to assist SCs and STs (and, to a lesser extent, $\mathrm{OBCs}$ as well). In addition to federal and state spending programs on social services in areas inhabited particularly densely by such groups, India has set aside reserved spots on civil service payrolls for SCs since 1943 and for STs since 1950. ${ }^{178}$ After 1947, some $12.5 \%$ of government jobs (normally recruited by open competition on an all-India basis) were reserved for Scheduled Castes and 5\% for Scheduled Tribes. ${ }^{179}$ In 1970 these figures were raised to $15 \%$ and $7.5 \%$, respectively. ${ }^{180}$ For noncompetitively selected national civil service posts, nearly $17 \%$ of jobs were reserved for SC members and 5\% (7.5\% after 1970) for tribals. ${ }^{181}$ Reserved positions are also generally accompanied by measures designed to make apphications less difficult for members' targeted groups. ${ }^{182}$ In the universities, centrally-funded scholarships provide an education to virtually any ST and SC member who applies-in numbers which grew from a mere 731 in 1948 to some 350,000 in $1975 .{ }^{183}$ In special authorization statutes which expire every ten years (but are invariably renewed), unembers of Scheduled

175. Marc Galanter, Competing Equalties: Law and the Backward Classes in India 4243 (1984).

176. See, e.g., Hariharan Pillai v. State of Kerala, 1968 A.I.R. (Ker.) 42, 47-48.

177. Triloki Nath v. State of Jammu \& Kashmir, 1967 A.I.R. (S.C.) 1283, 1285.

178. GALANTER, supra note 175 , at 86.

179. Id.

180. Id.

181. Id. at 86-87.

182. The Supreme Court even upheld a government regulation exempting SC and ST members from passing government examinations for two years. State of Kerala v. Thomas, 1976 A.I.R. (S.C.) 490,500 .

183. See Galanter, supra note 175 , at 62 . Income ceilings have been adopted for this program, but only at very high levels. SC and ST members are rarely denied the full scholarship. Some OBC scholarships existed until 1961, but they were much more competitive (and since that date they have been replaced by scholarships tied to economic need). Id. 
Castes and Tribes are also reserved seats in the lower house of the Indian Parhament (Lok Sabha) and in the lower houses of state legislatures (Vidhan Sabhas). ${ }^{184}$ In 1976 this scheine reserved 78 SC seats and 38 ST seats in the Lok Sabha (amounting to $14.4 \%$ and $7 \%$ of its total of 542 seats). ${ }^{185}$

The task of deciding which castes and tribes shall become "scheduled" (and thus eligible for preferential treatnent) is a inatter of governmental fiat. Under Articles 341 and 342 of the Constitution, castes and tribes inust be "scheduled" by Presidential Order in the first instance; hists of groups so recognized may only be inodified thereafter by a full Act of Parliament. ${ }^{186}$ This task of "scheduling" has been run throughout most of the post-independence period by the Ministry of Hoine Affairs, ${ }^{187}$ and is entirely a "pohtical" one. As one prominent "untouchable" politician from the independence period put it, "we have left it to be determined by each local Government. A backward comununity is a community which is backward in the opinion of the Government." 188 Arriving at a system of country-wide caste rankings was particularly difficult because the Hindu "caste system" varied greatly froin region to region. The British-appointed Simon Commission of 1930, for example, complained bitterly about the soinetimes poor correlation between the ritual indices of "untouchability" and the "practical disabilities" actually suffered by certain Indians ${ }^{189}$-a theine echoed wherever formal classification has been einployed.

The modern list of "scheduled" Indian groups originated when British Census Commissioner J.H. Hutton tried to squeeze India's variegated social practices into the neat conceptual boxes denanded by European sensibilities through the employ of an ad hoc mixture of social, religious, economic, educational and even residential considerations. ${ }^{190}$ Admitting the conceptual muddiness of the census caste tallies, India's post-independence government nevertheless uncritically adopted these designations as its own: the British list of 1936 was enacted almost unchanged after independence and has reniamed almost unmodified ever since. ${ }^{191}$ As Marc Galanter recounts in his voluninous study of the Indian system of preferential policies, "[t]he

184. Id. at 44-46.

185. Id. at 45 . Out of 3,997 seats in the various Vidhan Sabhas, the SC received 540 (13.5\%) and the ST 282 (7\%). Id.

186. Id. at 121-22.

187. Id. at 134. Between 1964 and 1973, however, these responsibilities were given to the Department of Social Security (later Social Welfare). Id. State and local governments play a consultative role in the scheduling process. The determination of areas reserved for scheduled groups, however, is a presidential prerogative alone. Id. at 148.

188. Id. at 160 (quoting Dr. Ambedkar).

189. Id. at 125 .

190. Id. at $127-29$.

191. Id. at 132 . 
selection of Scheduled Castes . . . has proceeded without benefit of a single connotative definition."192

One question which frequently confronts courts is whether membership in an ostensibly unlisted group can qualify an individual for special preference. This question arises when it is clear that an individual is a member of a particular group but unclear, due to either the ambiguities of nomenclature or the existence of subgroups, whether the group is entitled to preferential treatment. In some cases, the Indian Supreme Court has refused to address these matters at all on the grounds that any group not expressly named in the statute was to be left out. ${ }^{193}$ However, in other cases it has treated this question as susceptible to a more flexible, but still statutory, interpretation. ${ }^{194}$ In still other cases, it has been willing to go beyond the statute and admit evidentiary showings of facts such as customs shared by the two groups, and/or social acceptance of one group by the other. ${ }^{195}$ Cases involving questions of a group's entitlement to preferential treatment still uniformly rely on a "group-essentialist" assumption that individuals may clearly be categorized as a mentber of particular group in sone principled fashion.

More difficult questions arise when the classification of an individual is challenged. Legal challenges to a person's caste menibership have arisen, for example, in connection with elections to reserved legislative seats: is the victor "really" of the "scheduled" group? A person's menibership in a particular caste is generally, in some vague sense, left up to the caste itself. Because section 9 of India's Civil Procedure Code prohibits courts from recognizing purely "caste questions,"196 it has been held that a caste may, "if its rules and regulations so provide, admit a new member just as it may expel an existing member. ... [T] he ouly thing necessary for readmission would be the acceptance of the person concerned by the other members of the caste."197

When membership in groups eligible for job reservations or other benefits is contested, however, courts have looked to other indicia of member-

192. Id. at 134 .

193. See, e.g., Parsram v. Shivchand, 1969 A.I.R. (S.C.) 597, 600 (refusing to consider claim that two different appellations referred to the same caste); Bhaiya Lal v. Harikishan Singh, 1965 A.I.R. (S.C.) 1557, 1559-60 (refusing to entertain an included but not specifically mentioned "sub-group" argument).

194. See, e.g., Abhoy Pada Saha v. Sudhir Kumar, 1967 A.I.R. (S.C.) 115, 118 (recognizing two possible interpretations of the statute and rejecting the one that "might lead to such uncertainty").

195. See, e.g., Bhaiya Ram v. Anirudh, 1971 A.I.R. (S.C.) 2533; Siddapa v. Chandappa, 1968 A.I.R. (S.C.) 929, 931. Problems have also arisen because recognition of scheduled groups is sometimes undertaken in relation only to a particular area: a man who belongs to a Scheduled Tribe in one state might not be recognized as such in a neighboring state into which he has moved. See, e.g., Appa Rao v. Director of Posts \& Tels., 1969 A.I.R. (Ori.) 220, 221-22.

196. See GALANTER, supra note 175 , at 333 n.223.

197. Arumugam v. Rajgopal, 1976 A.I.R. (S.C.) 939, 948. Similar wording appears in Guntur Medical College v. Mohan Rao, 1976 A.I.R. (S.C.) 1904, 1908 ("The only requirement for admission ... is the acceptance of the person by the other members of the caste ...."). 
ship. In one early example, Chatturbhuj Vithaldas Jasani v. Moreshwar Parashram, ${ }^{198}$ the court ruled that a man had not ceased to be a member of a Scheduled Caste called the Mahars by virtue of his conversion to a Hindu sect that rejected caste divisions. In judging this issue, the court declared that such determinations depended upon "(1) the reactions of the old body, (2) the intentions of the imdividual himself and (3) the rules of the new order." 199 The man in question was still accepted socially by his old caste compatriots, and (as evidenced from his course of dealings with them) he appeared to intend to abide by the social rules of caste differentiation. Thus he remained an SC member. ${ }^{200}$ For moves from one Scheduled Caste or Tribe into another unit within the caste system, however, the completion of the move was held in Giri v. Dora ${ }^{201}$ to depend also upon one's acceptance by the "higher" (though legally nonprivileged) group. In other words, acceptance by the rest of society is dispositive. If society still regards one as a member of a Scheduled Tribe, one presumably still suffers the disadvantages of such consideration and thus should retain the benefits of scheduling; if one is now generally regarded as belonging to a nonscheduled group, no further benefits should accrue. The Giri approach-in contrast to Chatturbhuj Vithaldus Jasani-has as its conceptual strength the intuition that if social wrongs are allocated due to low caste status, social acceptance by a "higher" caste ought to end scheduling preferences as it ends the wrongs such preferences were designed to counteract. ${ }^{202}$ These questions often arise when the court is asked to decide whether someone can acquire ST or SC status through marriage and/or assimilation. Some courts have inquired first whether the conditions of a newcomer's accession to a scheduled group were enough to "destroy or nullify" the relative advantages of a

198. 1954 S.C.R. 817.

199. Id. at 838 .

200. Id. at 841-42. It was suggested, however, that a deliberate and final break with one's caste could remove caste status and any attendant preferential privileges under the scheduling system. Id. at 838.

201. 1959 A.I.R. (S.C.) 1318, 1327.

202. Chatturbhuj Vithaldus Jasani, on the other hand, looked at the SC member's acceptance by a Hindu sect that rejected the caste system altogether. If it is the object of group-preference programs to address remedial efforts to wrongs suffered on account of caste status, the more salient criterion in Chatturbhuj Vithaldus Jasani ought to have been whether or not the rest of Indian society still regarded him as a low-caste Mahar. Unless his conversion to this sect ended the disadvantages heaped upon him by virtue of his Mahar birth, his acceptance among the members of the sect itself would not seem particularly important. Note, however, that in Arumugam, the Supreme Court opined that

[o]nce a person ceases to be a Hindu and becomes a Christian, the social and economic disabilities arising because of Hindu religion cease and hence it is no longer necessary to give him protection and for this reason he is deemed not to belong to a Scheduled Caste. But when he is reconverted to Hinduism the social and economic disabilities again revive....

1976 A.I.R. (S.C.) at 949. If, indeed, it is possible for "social and economic" disabilities instantly to accrue (or dissolve) upon one's religious conversion, the Chatturbhuj Vithaldus Jasani and Giri cases are easily reconcilable. 
non-"untouchable" upbringing so as to justify acquiring scheduling protection. $^{203}$

Classification of "Other Backward Classes" is less rigid than for sclieduled groups. Caste criteria for determining OBC lists came under sustained legal assault in the 1960s and 1970s, amid concerns that for groups as broadly defined as $\mathrm{OBCs}$, caste-based allocation of preferences might fail to track real socio-economic disadvantages and allocate valuable (and controversial) privileges to some not deserving them. ${ }^{204}$ It was also increasingly perceived that in a society whose constitution was committed to eliminating caste-based differences among Indians, too broad a system of group-based benefit allocation might do more harm than good. ${ }^{205}$ Accordingly, the cabinet ended national OBC lists in 1961, reasoning that "economic backwardness rather than community or caste would provide an appropriate criterion for giving aid to individuals in matters of education including professional and technical training."206

The courts supported this shift in emphasis, holding that caste-based $\mathrm{OBC}$ classification could be challenged for failing to track real socio-economic backwardness. ${ }^{207}$ In Balaji v. State of Mysore, ${ }^{208}$ the Supreme Court reasoned that with $\mathrm{OBCs}$, some noncaste-based index of social backwardness was appropriate. Preference according to poverty alone, however, was still not endorsed, and the law in this area continued to require some undefined mixture of low caste status and real penury. ${ }^{209}$ State-run $O B C$ programs acquired income cut-offs barring aid to better-off caste members. ${ }^{210}$

The Indian system bears close structural similarities to our own dilemmas of affirmative action; in both cases it is comparatively easy to delineate "protected" groups, but very difficult to deal with individual claimants

203. See, e.g., Urmila Ginda v. Union of India, 1975 A.I.R. (Del.) 115, 116; Shantha Kumar v. State of Mysore, 1971 Mysore L.J. 21.

204. See. e.g., Chitralekha v. State of Mysore, 1964 A.I.R. (S.C.) 1823, 1834.

205. See Galanter, supra note 175 , at 176.

206. Id. (quoting from a Conference of Chief Mimisters to consider matters relating to National Integration).

207. Partha v. State of Mysore, 1961 A.I.R. (Mysore) 220, 230.

208. 1963 Supp. 1 S.C.R. 439; see also Chitralekha, 1964 A.I.R. (S.C.) at 1833 (finding no requirement that caste be taken into consideration at all in $\mathrm{OBC}$ classification); Rajendran v. State of Madras, 1968 A.I.R. (S.C.) 1012, 1014-15 (reasoning that if a caste is as a whole backward, it may be privileged as a caste, but this is differant from using caste qua caste); Triloki Nath v. State of Jammu \& Kashmir, 1969 S.C.R 103, 105 (admitting that a caste might be designated OBC for some preferential purposes, but this must be so only because it is, as a whole, a backward community and not because of any qualities inherent in its particular caste status).

209. See, e.g., Jayasree v. State of Kerala, 1976 A.I.R. (S.C.) 2381, 2386.

210. See generally Galanter, supra note 175, at 261-77. The advancement of members of Scheduled Castes and Scheduled Tribes has apparently not yet been such that similar worries about needless preferences for well-off (and thus undeserving) castemembers have produced income thresholds beyond which the benefits of scheduling do not apply. Galanter, however, suggests that the Indian courts might apply many of the OBC analyses to SC and ST cases in the future and require more attention to indices of socio-economic deprivation rather than merely those groups' ritual status within the Hindu social hierarchy. Id. 
or challenges to benefit allocation, given the absence of either an original population from which genealogical descent may be reckoned or which could participate in establishing its own membership criteria. While governmental agencies are responsible for the enumeration of "scheduled" categories, India commits to the judiciary concrete determinations that reward or deny benefits to individuals based upon group membership.

\section{American Segregation in the Era of Jim Crow}

Because America's pre-Civil War "peculiar institution" of chattel slavery permitted certain human beings to be bought and sold as property, adjudicating one's status as a "slave" must have been fairly straightforward: an initial deed of "sale" established an indefinite legal status of forcible indenture. The capacity of different human "races" to interbreed, however, soon posed problems for slave-owning British colonies established on the shores of North America, and early anti-miscegenation laws ${ }^{211}$ originated in large part to control the legal consequences of interracial relations. Such laws were established in Virginia in order to regulate the legal status of a BlackWhite child as early as 1662 (when chattel slavery was becoming common). Children of mixed inarriages were to be held as slaves or free persons according to the status of their mother. ${ }^{212}$ In 1664, Maryland began prohibiting inarriage between freeborn English woinen and Negro slaves. ${ }^{213}$ All children whose fathers were slaves would be slaves for life, and all free women who married slaves would becoine slaves as long as their husbands lived. ${ }^{214}$

These earliest laws focused upon relationships between free persons and slaves, and were not directed at Blacks qua Blacks. However, general laws barring sex and marriage between any White and any Black soon superceded this approach. The presence of a small population of free Negroes contributed to anti-miscegenation laws based unabashedly upon color prejudice. Between 1800 and 1860, "[f]ree persons of color" made up between $10 \%$ and $14 \%$ of the Negro population of the United States, and this group grew at a faster rate than did the overall Black population until about 1810.215 For White racists, the presence of this free Black population raised a perceived need to protect White "blood" from "pollution," which

211. The term here is used to include laws banning sex, concubinage, or bastardy between members of different races, as well as laws prohibiting marriage between members of different races.

212. David H. Fowler, Northern Attitudes Towards InterRactal Marriage: Legislation and Public Opinion in the Middle Atlantic and the States of the Old Northwest, 1780-1930, at 35-36 (1987).

213. Id.

214. Id. at 41 .

215. Thomas Sowell, Three Black Histories, in Essays aNd DaTa on AMERICAN ETHNIC Groups, supra note 134 , at $7,9-10$. Unlike the slave population (less than six percent of which lived in the northern states at any time), the free Black population was relatively evenly distributed between the regions that would later becoine known as the North and the South. BUREAU OF THE CENSUS, DeP'T OF Commerce, Negro Population, 1790-1915, at 55 tbl. 2 (1918). 
soon resulted in formal racial classification of all persons, and legal restrictions on previously (legally) unregulated relations between Whites and free Blacks. With Einancipation in 1865, this "problem" was inagnified enormously, leading to the elaborate edifice of "Jim Crow" segregation which the Court gave constitutional sanction in the infamous Plessy $v$. Ferguson. ${ }^{216}$

For this system of segregation to function effectively, some way had to be established to define what it was to be a "Negro." The racial definitions in the laws of the Jim Crow era were rooted in a matrix of underlying "racialist" assumptions, including that mankind is divided in some primordial sense into discrete race blocs somehow objectively distinguishable enough to enable fractional-descent calculations like " $1 / 8$ Negro blood." In practice, without any clear method for defining discrete base populations, Jim Crow laws were grounded in no more than stereotype-driven "intuitiveappraisal" tests. Mr. Plessy could not ride in that notorious "Whites Only" rail car in Louisiana because he was not a White, but rather, a Colored man, an "Octaroon." He was, however, an "Octaroon" not in the genuinely scientific sense in which he was "male" (the possessor of both an X and a $Y$ chromosoine), but because one of his great-grandparents possessed some vague amalgam of physical and cultural characteristics that led White Southerners to judge him or her a "Negro" of "full" blood.218 Without somehow defining a base population, fractional-descent calculations could not be coherent. As with all such designations, these legal categories had to have some inethod of person-by-person ascription of identity based on cultural, racial, and ethnic stereotypes.

Soine jurisdictions acknowledged this reliance on stereotyping with inore candor than others. Missouri went so far as to provide by statute that the possession of "1/8 or more Negro blood" was a characteristic determinable by a jury from the appearance of the person in question. ${ }^{219}$ Ohio's 1861 mixed-marriage prohibition defined persons falling within its rubric as "any negro, or person having a distinct and visible admixture of African blood,"220 while Georgia once categorized "all negroes, mulattoes, mestizoes, and their descendants, having any ascertainable trace of either

216. 163 U.S. 537 (1896), overruled by Brown v. Bd. of Educ., 347 U.S. 483 (1954).

217. David Fowler provides a comprehensive survey of anti-miscegenation laws in 40 states; many of these laws rely upon exactly such a precise calculation. See FowLER, supra note 212, at 339-439. Even where terms like "Mulatto" were actually defined (which was rare), the definitions employed merely removed the ambiguity one step: in 1803 the laws of the "Indian Territory," for example, defined "Mulatto," but defined it merely as a person with one-fourth or more "Negro blood." Id. at 124.

218. Despite the lip service paid to a reified "objective" concept of "racc," no coherent definition is really present in any of these statutes. If "full" blooded Negroes were defined as those persons descended exclusively from people who all lived in Africa until the coming of European slavers, few African-Americans would likely qualify (Mr. Plessy's Black great-grandparent or the allegedly Black Sarah Carroll of the Malone v. Haley saga imcluded).

219. See Fowher, supra note 212, at 394-96.

220. See id. at 201 (emphasis added). 
Negro or African, West Indian, or Asiatic Indian blood in their veins."221 This focus upon the "ascertainability" of non-White "taint" was, at least, an honest admission of the subjectivity of such classifications. In the case of anti-miscegenation laws, for example, individual determinations could be left to state officials tasked with signing marriage licenses and other official forms. Under Virginia law, if a court clerk had a "reasonable cause to disbelieve" claims of racial identity, he could withhold the issuance of a marriage certificate until more satisfactory "proof" was supplied. 222 When a system of statewide (though voluntary) race-registration was begun, the penalty for making a "false" self-reported designation was a year in prison. ${ }^{223}$ Virginia's Bureau of Vital Statistics began a practice of making notations on the back of birth certificates which the Registrar believed may indicate an "incorrect" race. ${ }^{224}$ On the basis of these notations, a family could be refused birth certificates for future children until all "false" certificates were re-classified "properly" in the clerk's opimion. ${ }^{225}$ Officials could even re-classify individuals sua sponte "after securing additional information."226 In this way, Virginia's State Registrar for Vital Statistics "firmly refuse[d] to admit [persons] as white if they ha[d] even a trace of Negro blood on either side." $" 227$

Thus, segregationist America employed a variety of approaches to racial classification in its attempts to deal with classificatory dilemmas. For the most part the origins of classification went unquestioned: it seemed to be taken for granted that the possession of some specified fraction of Negro "blood" would be so apparent that serious thought need not be devoted to devising any process of determination. In practice, this was an administrative solution, which jurisdictions like pre-desegregation Virgimia had the candor to recognize, evidenced by the practice of committing determinations of race to the clerks and petty bureaucrats in the office of Vital Statistics. In other jurisdictions, such as Missouri, the process was given to the courts, holding firmly to the common law tradition of entrusting such "facts" to the institution of a jury well acquainted with social convention and prevailing stereotypes: a judicial, formalized version of the "visual sur-

221. See id. at 362 (emphasis added).

222. Paul A. Lombardo, Miscegenation, Eugenics, and Racism: Historical Footnotes to Loving v. Virginia, 21 U.C. DAvis L. REv. 421, 436 (1988).

223. Act to Preserve Racial Integrity, ch. 371, 1924 Va. Acts 534; see also Lombardo, supra note 222 , at $436 \&$ n.69.

224. This practice was later codified. Act of February 22, 1944, ch.52, 1944 Va. Acts 51, 54. The registrar is to make such notation if "public records concerning such person or his or her parents or forbears are such as to cause the Registrar to doubt the correctness of the racial designation or designations contained in the certificate." Id.

225. Lombardo, supra note 222, at 448.

226. Id. at 433 (quoting letter from Walter Plecker to M.B. Booker, State Senator, Virginia (Feb. 15 , 1924) (on file at the Univ. of Va, Manuscript Dep’t, John Powell Collection \#7284)).

227. Id. at 430 (quoting Walter Plecker, Bureau of Vital Statistics Finds Solution [to] Puzzle, NEws LEADER, Aug. 4, 1923, at 22). 
vey" approach recommended by the EEOC.228 Whether it followed the judicial or the bureaucratic-administrative paradign, the classification scheme of the Jim Crow era followed an approach closer to the Giri than to the Chatturbhuj Vithaldus Jasani line of Indian jurisprudence-namely, a nonmember-referent standard which looked primarily at whether the clainiant was accepted by the rest of society as a member of the class in question, rather than to her acceptance or rejection by that class itself. This approach was also, to some extent, taken by the National Party government of South Africa.

\section{Classification in the Apartheid State}

South Africa's system of apartheid was built upon a statutory system of race classification which tied every aspect of social and economic life, and even "national" affiliation, to individual classifications. In its philosophical scope, the apartheid scheme went far beyond the segregationist aspirations of the Jim Crow South, enconipassing also an ideal of complete political and territorial separation. In the full flowering of what the governing Afrikaner-dommated National Party termed (without conscious irony) a system of "separate development" and "separate freedonis," it was argued that the individual developnent of the various racial "nations" of South Africa would in tine produce a patchwork quilt of sovereign states living alongside each other in relationships of economic interconnectedness but political independence. ${ }^{229}$ Ultimately, "South Africa" itself would be a purely White state, surrounded by distinct "national" or "tribal" homelands confederally allied to it. This sweeping articulation of a "separate but equal" doctrine of absolute partition rationalized the apartheid state's allembracing system of racial segregation and discrimmation-from the everyday inatters of public amenities to the wholesale deniarcation of inpoverished and discontinuous quasi-colonial "homelands" (or "Bantustans"), such as Bophuthatswana, KwaNdebele, KwaZulu and Transkei, which were reserved for South Africa's tribal "nations" (Twsana, Ndebele, Zulu, Xhosa, etc.). ${ }^{230}$

228. See supra text accompanying note 99.

229. As South African Prime Minister B.J. Vorster put it in a 1974 speech to the South African Senate, "independent states and peoples can live here in their own right, in this territory which is known today as the Republic of South Africa." B.J. Vorster, Select Speeches 224 (O. Geyser ed., 1977).

230. The implementation of "separate development" theory never, of course, lived up to its stated philosophical aspirations. The homelands allocated to each of the region's Black "tribes" never amounted to more than about thirteen percent of the total territory of South Africa, and excluded the most important manufacturing centers and natural resources. The homelands renuained little niore than inipoverished labor pools for the White-run industries and resource-extraction operations within the White-reserved areas of the country. For many years Blacks outside their "honielands" were treated as "temporary" visitors from independent sovereign states (as night, for example, bo a Mozambican migrant laborer). A series of "influx control" laws (including the infamous "pass laws") regulated Blacks' access to White areas, and consigned unillions of Blacks to "temporary" residence in sprawling 
The backbone of the apartheid state was a system of universal population registration, which wrote into law the classification of individuals into discrete groups. Under section 5 of the Population Registration Act of 1950:

(1) Every person whose name is included in the [census] register shall be classified by the Director [of the Census] as a white person, a coloured person or a native, as the case inay be, and every coloured person and every native whose name is so included shall be classified by the Director according to the ethnic or other group to which he belongs.

(2) The Governor-General may by proclamation ... prescribe and define the ethnic or other groups into which coloured persons and natives shall be classified in terms of sub-section (1), and may in like manner amend or withdraw any such proclamation. ${ }^{231}$

The original text of the Act defined South Africa's racial groups as follows:

(iii) "coloured person" Ineans a person who is not a white person or a native; ...

(x) "native" means a person who in fact is or is generally accepted as a member of any aboriginal race or tribe of Africa; . . .

(xv) "white person" means a person who in appearance obviously is, or who is generally accepted as a white person, but does not include a person who, although in appearance obviously a white person, is generally accepted as a coloured person. ${ }^{232}$

The operation of this classification systein can perhaps best be seen $\mathrm{m}$ the procedures provided for racial "re-classification." Benefit-allocation was strongly tied to racial classification-for example, residential areas were segregated under the Group Areas Act, intergroup inarriages were prohibited by the Prohibition of Mixed Marriages Act, intergroup sex was banned by section 16 of the Immorality Act, and public facilities were segregated by the Reservation of Separate Amenities Act. ${ }^{233}$ In such a system it was not uncommon for inany individuals to wish to challenge the classification they had been assigned. For example, a "coloured person" could enjoy greater benefits if he could be reclassified as a "white person."

townships and squatter camps. See generally ILLuSTRATED History OF SOUTH AFrica 375-81, $424-33$ (Dougie Oakes ed., 1988).

231. An Act to Make Provision for the Compilation of a Register of the Population of the Union; for the Issue of Identity Cards to Persons Whose Names Are Included in the Register; and for Matters Incidental Thereto, No. 30, $\$ 5$ (1950) (S. Afr.) [hereinafter Population Registration Act].

232. Id. at $\S 1$ (iii), (x), (xv).

233. Illustrated History OF SOUth Africa, supra note 230, at 375-77. 
By choosing a classification scheme based on an "in appearance obviously is, or who is generally accepted as"-standard, the architects of apartheid were shrewd enough to avoid any scientific definition of race or ethnicity. In essence, the government had the power to classify and reclassify individuals at will. ${ }^{234}$ Section 5 of the Population Registration Act provided:

If at any time it appears to the Director that the classification of a person in terms of sub-section (1) is incorrect, he may . . . after giving notice to that person ... specifying in which respect the classification is incorrect, and affording such person ... an opportunity of being heard, alter the classification of that person in the register. ${ }^{235}$

Re-classifications at an individual's own request were inore complicated. Applicants would be deemed members of a racial group only if other designated members of that group accepted them as inembers, as determined by a panel of "experts" commissioned for the occasion. Section 11 of the Act regulated challenges to individual classification orders:

(1) Any person who considers himself aggrieved by his classification by the Director in terms of section five and any person who has any objection to the classification of any other person in terms of the said section, may at any time object in writing to the Director against that classification.

(2) Every such objection shall be lodged in duplicate and shall be accompanied by an affidavit in duplicate setting forth fully the grounds upon which the objection is inade, and if the objection relates to the classification of a person other than the objector, a copy of the objection and the affidavit shall be transmitted by the Director to the person to whose classification the objection relates.

(3) Every objection received ... shall be referred by [the Director] . . . to a board . . . constituted for the purpose by the Minister ....

(5) ... [T] The Director and every objector and every person in regard to whose classification the objection has been made, shall be entitled to appear before the board concerned ... to cross-examine wituesses and to adduce such evidence as may be relevant to the matter before the board ....

(7) The decision of a board shall be final and binding upon all persons including the Director: Provided that any person who considers himself aggrieved by a decision of a board in regard to his

234. This, of course, had first been done on a huge scale with the promulgation and implementation of the Population Registration Act, supra note 231.

235. Id. at § 5(3). 
own classification may ... appeal against that decision ... to the provincial or local division of the Supreine Court of South Africa $\ldots .{ }^{236}$

Under section 11, one could even challenge the racial classification of another person, making it possible for a concerned citizen to have a suspect neighbor "expelled" from his racial category.

The standards such boards employed revolved around not whether an applicant for re-classification was socially acceptable to the inembers of the group to which lie or she had asked to be admitted, but rather whether the racial group members felt the applicant actually to be a member of that racial group. In other words, it would be legally irrelevant for re-classification purposes that White citizens were willing to welcome a Coloured applicant into their hitherto White-reserved neighborhood. Re-classification would be permissible only if they were willing to swear that the applicant was in fact not Coloured at all but really White. One opposition parliamentarian described the process as follows:

One must have photographs taken-colour pictures; front and side views - on the basis of which somebody can judge whether one can pass as White. One has to appear before a committee of officials who will then listen to one's pronunciation of English or Afrikaans or whatever other language in order to judge whether one will fit in

One has to obtain opinions from other people in one's community ... as to whether one is acceptable to Whites as a White.

... [One must obtain opinions that one is] acceptable in a White community as a White person. ${ }^{237}$

Such was the race-classification scheme of apartheid.

The South Africans thus took "intuitive appraisal" tests to a relatively high level of formality, establishing an extensive judicial and bureaucratic system for the allocation and re-allocation of racial identity. There, summary bureaucratic authority to allocate racial identity was the rule, but formal procedures were provided for individuals to challenge the classifications thus made. For a society that took its racism and its legal formality seriously, there was scarcely any way to avoid building such an elaborate classificatory edifice. The centrality of racial identity in South Africa to the allocation of even the most basic necessities of everyday life-let alone those precious civic commodities of citizenship, voting power, nationhood, and civil and political rights-deınanded nothing less.

236. Id. at $\S 11$.

237. 2 Parl. Deb. (Hansard), House of Assembly 4435-36 (1988) (statement of S.S. van der Merwe) (emphasis added). 
IV

\section{THE CATEgory CONUNDRUM}

The classification systems we have seen thus far each contain elements of the two basic paradigms of group classification: self-reported identity and sub-varieties of other-ascription. None of the systems we have examined are purely one or the other, with the possible exception of the FBI crime statistics system, in which individuals appear generally to be classified solely according to the group to which they are perceived to belong by the official filling out the report. The Massachusetts test of Malone v. Haley looks like a combination of an other-ascribed "visual survey," "documentary evidence" predicated upon some unspecified antecedent method of classification (i.e. the NCHS birth certificate system), and a kind of racial self-reporting with estoppel characteristics (i.e. whether or not individuals have "held themselves out in the community" as being of a certain race). The Census uses a system of almost exclusive self-reporting, but modifies data to some degree when that information is "incomplete" (i.e. people do not wish to assign themselves a racial identity), arrives in a nonstandard form, or-in the case of non-tribe-specific American Indian responsesresults in numbers being reported that differ sigmificantly from "actual" numbers.

The NCHS system for birth certificate coding is now based upon selfreporting by a child's mother (though nonstandard responses are coded back into the basic categories), with the race of the child ascribed based upon the race of the mother. However, until recently, the NCHS system combined elements of a formulaic lineal system that defined group membership by comparing the self-reported races of the parents. EEO classification awkwardly incorporates both self-reported census data and otherascribed intuitive-appraisal tests by employers. United States Indian law has in recent years tended towards a system of political definition, but elements of the other systems have been used in the past, and the present state of the law still refers ambiguously to fractional percentages of "blood" content. ${ }^{238}$ The anti-miscegenation laws of the Jim Crow period varied considerably, but most often used a hineal descent system which looked to fractional "blood" content; this system was in turn predicated upon the existence of a base population defined by some other-ascribed method. Internationally, India's system of adjudicating SC and ST membership took the basic group classifications as pre-ordained by governmental authority, but placed individuals into them according to variously-defined criteria of social acceptance (while requiring $O B C$ preference programs to incorporate criteria of economic necd). Finally, South Africa employed a system of political fiat modified by other-ascription tests in its adjudication of challenges under its population registration laws.

238. See supra text accompanying note 172 . 
Each of our basic paradigms entails its own difficulties. Self-reporting is perhaps the method most congruent with the individualist values of American society, but it is perhaps awkward and artificial in the context of racial and ethnic identity - which our culture treats as almost axiomatically beyond the choice or "will" of the persons so identified. ${ }^{239}$ More significantly, the Malone case illustrates its theoretical weakness as a basis for the allocation of real benefits through remedial programs. If the Malone twins had not marked themselves "White" on their 1975 civil service examination and had indeed "held themselves out in the community" as Blacks, would they deserve affirmative action promotion? If group-specific preferences are supposed to remedy the ill effects of past and ongoing discrimination, pure self-reporting threatens to erase the necessary logical connection between disadvantage and remedial preferment. Would Paul and Philip Malone deserve preferential treatment by virtue of believing themselves Black, even without being considered Black by the rest of the communityand thus presumably having suffered none of the disadvantages usually associated with that status? The remedial goal of putting victims in the positions they would have been in "but for discrimination" would, in such circumstances, demand something more socially authoritative than mere self-reporting.

The ability of self-reported classification to act as a proxy for "real" patterns of social disadvantage is thus highly questionable. Such a system might require soine form of "monitoring" in order to ensure the necessary connection between self-reported identity and the disadvantage targeted by remedial preferences. Too many "Malones" in such a system, and it could collapse. Furthermore, since perceptions of imdividual self-identity are not fixed, the same individuals may give different self-reported responses over time, in different contexts, or for different purposes. ${ }^{240}$ As we have seen from the example of Puerto Rican census classification recounted by José Cabranes, ${ }^{241}$ it may be "meaningless" to compare statistics based on selfreporting from one locale to those based on self-reporting from another. This may be true over time as well as over geographic distance.

Other-ascribed systems are not without their own problems, however. Their strength, from the standpoint of remedial preference programs, is that they, of our two paradigms, may more closely approximate the ways in which society allocates disadvantage. This, however, is far from certain. Other-ascribed systems must choose between the member-referent and nonmember referent standards of group identity-in effect, between the Chatturbhuj Vithaldus Jasani and Giri standards of Indian jurisprudence. ${ }^{242}$ Should Paul and Philip Malone be classified as Black depending upon

239. See, e.g., Fiss, supra note 46, at 243.

240. See, e.g., Gordon, supra note 66.

241. See supra text accompanying note 68 .

242. See supra text accompanying notes 198-202. 
whether some relevant population of Blacks accepts them as members of the Black community? Or should we look to whether Whites treat the Malones as Black persons? Since the distribution of racial disadvantage is presumably keyed to how the rest of society perceives the claimant, the nonmember-referent (Giri) standard would appear the most likely to target remedy to wrong. Preference would be given an individual, for example, not according to Blacks' feelings of solidarity with her but rather according to whether or not the majority White population-the presumptive source of the wrong being done-perceives her to be Black. It would certainly seem a poor remedial system which denied someone an anti-discrimination remedy because she was not felt "Black" by Blacks, if at the same time the rest of the population treated her as if she were.

Interestingly, this nonmember referent standard is precisely the definitional criterion used in South African race reclassification hearings where admission to a more-advantaged group is sought: witnesses from the more privileged group are asked not to assess their general social acceptance of the claimant but, rather, to reveal whether or not they feel her to be a fellow member of their racial group. The South African system differs from programs of remedial preference, of course, in that its race classification was fundamentally malign in nature while remedial "affirmative action" attempts to make amends for past and present wrongs. It is certainly counter-intuitive to suggest that proponents of modern affirmative action might learn something from the evils of the apartheid state. Nevertheless, South Africa was a society in which racial classification was of fundamental importance and considerable resources were devoted to its administration; it went further, perhaps, than any other state in establishing what might be called a sort of classificatory "due process."

Once a standard of reference is chosen, an other-ascribed classification system must identify the "other" to whom it entrusts the power to apply this standard-and must come up with methods of regulating that entity's power and discretion in ways appropriate to the constitutional system. To whom are we to entrust the task of deciding whether the Malones are-by whatever conceptual reference standard-“"really" White or "really" Black? We have seen, in our comparisons of classification systems, two basic procedural models: the bureaucratic-administrative and the judicial. Classification in pre-civil rights Virgima was carried out by state bureaucrats, and the court clerks who issued birth and marriage certificates denied their services to anyone they deemed "incorrectly" classified. In Missouri the relevant "other" was more judicial, taking the form of a full jury convened for the occasion of deciding whether or not someone was of oneeighth or more Negro descent. India also gives its classification decisions to the judiciary, but apparently to judges rather than to juries-with the result that there has developed a fairly extensive common law of caste clas- 
sification. South Africa employed elaborate administrative procedures, but made decisions appealable to a court of law.

In the United States today, however, there is no clear allocation of such decision-making authority. The census data that forms the backbone of electoral redistricting and MSA databases is derived fron individually self-reported sources. On the other hand, businesses are encouraged themselves to conduct "visual surveys" to determine how many-and whichminorities they employ. This is clearly an other-ascription approach, but one that provides no real standards or guidelines for judging group membership. Apparently, each individual personnel admimistrator may employ whatever reference standard or standards he wishes. ${ }^{243}$ This procedure is also highly decentralized and conducted, without meaningful oversight or accountability, by private employers who have some interest in particular outcomes. With regard to contesting self-reported identities in public employment, as in Malone $v$. Haley, the courts seem to put great faith in the on-the-spot expertise of administrative hearing officers-who themselves may look to various self-reported or other-ascribed sources of information. No formal procedure appears to exist for contesting classifications in private employment, though one imagines that complaints might simply result in management permitting greater employee self-identification.

Never having had formally to choose a classification method or to confront head-on the dilemmas of categorization, it seems that the U.S. has managed to pretend that such choices are not made. We like to assume the objective reality of the categories we employ, and give little thought to their derivation. But for a project as volatile and constitutionally "suspect" as that of race classification, how long can we allow such ad hoc procedures to underpin so much of our public policy administration and jurisprudence? People like Paul and Philip Malone are beginning to force us to confront how it is that our system makes such determinations, and we may be uneasy with what we see.

There is something of a "tragic choice" dimension here. Other-ascription, as a paradigin, produces some need for what Calabresi and Bobbit have called an "aresponsible agency"244 tasked with applying classificatory standards. The actual formal classification of individuals by race is a difficult and potentially disturbing task, particularly given the baggage of oppression and segregation historically associated with such efforts. Yet as long as we pursue remedial programs of group-keyed preference, such decision-making cannot be avoided. As with the Calabresian example of decisions allocating the scarce resource of artificial kidney machinery, race

243. Whether or not such a standard turns out to be member-referential or nonmember-referential, could depend on the race of the individual tasked with making such classifications.

244. Guido Calabresi \& Philip Bobbit, Tragic Choices 57 (1978) ("The aresponsible agency generally has three features: It is representative, decentralized, and it gives no reasons for its decisions."). 
classification is a type of necessary decisionmaking that is most conveniently done in the shadows, so as to allow us more easily to pretend it really isn't happening. Entrusting such power to a bureaucracy"assigming responsibility to a priesthood" as Calabresi and Bobbit put $\mathrm{it}^{245}$-or consigning it to the hallowed secrecy of the jury room can "make the grounds for decisions less direct and perhaps even less obvious, while at the same time trying to make sure that the decisions are based on broadly held social values."246

The virtues of a jury approach, it has been suggested, lie in its representativeness and $m$ the way in which its determinations are considered "findings of fact." Because a jury's decision is considered a factual one, in most jurisdictions it is well isolated from subsequent scrutiny. "Juries apply societal standards without ever telling us what these standards are, or even that they exist. This is especially important in those situations in which the statement of standards would be terribly destructive."247

A bureaucratic approach, by contrast, invites appeal from adverse decisions, thus exposing the process. Sucl was the case when the decisions of the Malones' personnel administrator were reviewed by Judge Wilkins. Even a jury-based approach, however, might run into bizarre problems of application: could circumstances arise, for example, in which-as sometimes occurs with more conventional factual findings by a jury - an appellate court might hold as a matter of law that no rational jury could have found claimant X genuinely to be a Black man? What standards of case law and precedent would develop out of such jurisprudence?

Still more nagging questions remain. Would classification decisions made by a bureaucrat or by a jury be given any estoppel value? Once identified as belonging to a particular race for one purpose, would one be held to that category for any and all other purposes? How would this be accomplished, particularly in the case of "close calls"? What sort of recordkeeping would be necessary or appropriate for this task? Recall that Judge Wilkins considered the fact that the Malones' parents and grandparents had birth certificates mdicating that they were White: could the children of parents both of one race be estopped from subsequently claiming to be of another? If the law is to admimister benefits according to group membership, our notions of legal-even constitutional-propriety may force us to answer a blizzard of awkward questions and to develop an entirely new jurisprudence of classificatory "due process."

This is, indeed, our dilemma. If we are serious about writing laws and regulations tying benefits to racial or ethnic categorization, it may no longer be possible to avoid taking a hard look at the processes by which we define groups and draw lines between rival claimants. The administration of our

245. Id. at 69.

246. Id. at 71 .

247. Id. at 57 (citation omitted). 
extensive corpus of anti-discrimination law and preferential policy requires that we make "hard" variables of the very "soft" concepts of race and ethnicity. The case of the "Mixed-Up Malones" suggests that at some poimt we will be forced to justify the methods we employ or allow to be eniployed. Of all the systems we have examined, only India, South Africa, and a handful of the old Jim Crow jurisdictions confront the dilemmas of classification with relative honesty. True, the latter two undertook such efforts for the purpose of imflicting harm rather than doing good, yet all three at least faced up to the necessity of drawing lines. It would be iromic indeed if for the mtelligible administration of modern anti-discrimination law we borrowed our models of procedural rectitude in part from our own segregationist past or from the apartheid state of South Africa. However, if we are to administer a race-conscious public policy, we have to understand that categorization requires method.

Malone v. Haley tells us that some such form of proceduralization is a necessary adjunct to the administration of a group-keyed public policy. This entails considerable cost: a coherent system of group benefit-allocation requires more attention to the process of classification than has hitherto been given, but this attention may solidify the very social divisions beyond which preferential programs were ostensibly designed to move us. Many will thus doubtless suggest that there is something profoundly wrong with an "anti-discrimmation" ethic which calls forth such jurisprudential segregation and brands badges of racial identity onto the face of public life, insisting that the real problem lies deeper in the group-essentialist paradigm rather than merely at the level of procedural propriety. If we must maintain a category-conscious public policy, however, we will have to face up to the dilemmas of drawing lines and of considering what "process," in this respect, we are all "due." 
